\title{
Espaço e Etnia
}

\section{GERD KOHLHEPP*}

$\mathrm{D}$

esde 1824 os Estados do sul do Brasil revelaram-se ser, em diferentes concentraçóes espaciais, regióes de acolhida de uma colonização agrária dirigida, governamental ou particular, de imigrantes alemães; que foram se assentando de maneira coesa e etnicamente homogênea na regiáo das florestas tropicais e subtropicais como colonizadores das florestas por meio de derrubadas.

Nas tradicionais regióes de assentamento da população teuto-brasileira no Rio Grande do Sul e em Santa Catarina, que não mais sofreram uma imigração direta dos países de origem no século $\mathrm{XX}$, a falta de continuidade de impulsos inovadores alienígenas, a necessidade de adaptaçóes econômicas, a mobilidade espacial, regióes planejadas de colonizaçáo mista no âmbito da migraçáo intra-estadual em etapas, assim como uma mudança geral das estruturas sociais e econômicas, geraram uma alteração dos padrōes de comportamento etnicamente impostos para padrōes determinados mais por grupos sociais diferenciados e específicos por regiăo. Isto vale igualmente - com exceçóes - para a migração interna em direçāo às regiōes pioneiras mais recentes do Centro-Oeste e da Amazônia (vide o artigo de LÜCKER neste tomo).

Porém, generalizaçōes inadmissíveis referentes à mega-região "Sul do Brasil" não consideram a posição particular ocupada pelo Estado do Paraná em diversos níveis no contexto das atividades de natureza espacial dos grupos de imigrantes europeus e sobretudo alcmães.

O Paraná é o único Estado brasileiro no qual, mesmo depois da $2^{\mathrm{a}}$ Guerra Mundial, foi possível o assentamento de grupos maiores de imigrantes europeus, homogêneos étnica e socialmente, em povoaçóes coesas.

Além do mais, o governo estadual do Paraná seguiu, com a fun-

* Gerd Kohlhepp é professor e diretor do Instituto Geográfico da Universidade de Tübingen, Alemanha. 
dação de colônias agrárias, uma estratégia de desenvolvimento combinada de elementos do espaço natural, econômico e social, que levou a uma alteração de paradigmas na agropecuária brasileira: não seriam mais as florestas, mas sim as regióes dos campos limpos (1) o campo de açáo das atividades agroeconômicas.

Simultaneamente iniciou-se a propagaçăo de um novo sistema empresarial agropecuário, que seria a agropecuária mecanizada, assim como a promoçáo específica do cultivo de trigo, um alimento básico, cuja demanda no Brasil era em $\mathbf{9 0 \%}$ coberta por importaçóes.

Uma primeira fase de atividade agrícola na campanha do Rio Grande do Sul, efetuada por açorianos entre 1785 e 1820, marcada por um apreciável cultivo de trigo (WAIBEL 1955, PFEIFER 1967), revelouse apenas como excessão que comprovou a regra vigente na América do Sul de que "a colonizaçáo agrária dos campos foi posterior à das matas virgens" (WILHELMY 1940, p. 216).

Depois de falharem as tentativas anteriores de colonizaçáo dos cam-. pos por alemães do Volga (1877-79) (BREPOHL/FUGMANN 1927), a colônia holandesa de Carambeí, nos campos limpos de Ponta Grossa, transformou-se no centro contemporâneo de inovaçóes para a economia eficiente nos campos (WAIBEL 1955), que, porém, mais tarde especializou-se na criação intensiva de gado leiteiro em pastagens artificiais. Em Carambeí constituiu-se a primeira cooperativa de laticínios do Brasil. Também as colônias holandesas nos campos de Castrolândia (1951) e Arapotí (1959) (VAN SANTEN 1966), assim como nos menonitas (2) de Witmarsun (PAULS 1980), que se mudaram de Santa Catarina para os campos paranaenses em 1951, tinham o foco central das suas atividades na criação de gado leiteiro (cf. PFEIFER/KOHLHEPP 1966).

Igualmente no âmbito dos esforços específicos do governo estadual do Paraná, visando a valorizaçáo agrícola dos campos, criou-se a colônia de Entre Rios, em 1951, nos campos de Guarapuava, com aproximadamente 2.500 suábios do Danúbio, fundando assim o maior assentamento de imigrantes étnica e sociamente homogêneos no Brasil depois da $2^{\mathrm{a}}$ Guerra. O professor universitário, governador do Paraná e posterior ministro da Agricultura, Bento Munhoz da Rocha Neto, partiu, na sua política de colonizaçáo dos campos do Paraná, da combinaçáo de "assentamento e produção dirigida", assim como do assentamento de "grupos de população homogêneos", que deveriam trazer conhecimentos agrotécnicos das suas regióes de origem e que deveriam produzir com orientaçáo ao mercado (ELFES 1971, GAPPMAIER 1987). Devido à distância do mercado consumidor nāo foi possível a criaçáo intensiva de gado leiteiro em Entre Rios e assim quiz-se, pela primiera vez, concentrar a agropecuária nos campos nas atividades tritícolas. 
Porém justamente oestabelecimento de colônias de imigrantes etnicamente homogêneos havia sido não só largamente combatido no Brasil, como também - até mesmo em conseqüência das atividades da organização para o exterior do partido nazista alemão - proibido por lei através de uma convençáo de quotas de 1940 . Esta convenção estabelecia que no mínimo $\mathbf{5 0 \%}$ dos habitantes de uma colônia deviam ser brasileiros e que no máximo $25 \%$ podia ter a mesma nacionalidade estrangeira (FOUQUET 1974).

É interessante observar que também Leo Waibel e o seu grupo de trabalho brasileiro, devido aús seus estudos sobre a avaliação da colonização européia no sul do Brasil na segunda metade dos anos 40 , havia chegadoà conclusão de que, para garantir um bom começo e por critérios sócio-culturais e psicológicos, cada povoação isolada de imigrantes deveria formar uma pequena comunidade nacional, sendo que deveria haver a possibilidade de os povoamentos de diversas nacionalidades situarem-se lado a lado, mas deveria-se evitar o surgimento de grandes assentamentos coesos (WAIBEL 1955, pp. 134/35). Mas foi justamente isto que foi posto em prática na política de colonizaçáo no Paraná no início dos anos $\mathbf{5 0 .}$

\section{As Condiçóes do Espaço Social e Econômico da Colônia dos Suábios do Danúbio em Entre Rios}

Os colonos suábios do Danúbio são originários das antigas regióes Sírmia, Eslavônia, Batchca e Banat, situadas, depois da quebra do Império Austro-Húngaro após a $1^{2}$ Guerra Mundial, nos países Iugoslávia, Romênia e Hungria. Eles possuíam uma longa tradição agropecuária, tendo o trigo como cultura principal e uma organizaçáo em cooperativas que, no entanto, divergia regionalmente quanto à intensidade (3).

Depois da expulsão e da fuga em decorrência da $2^{\text {a }}$ Guerra Mundial, seguida de alguns anos de estadia na Austria, sobretudo no sul, eles chegaram ao Paraná em 1951, por intermédio da "Schweizer Europahilfe" (iniciativa suíça de "Auxílio à Europa" ), como parte de um grupo de emigrantes bem maior no princípio - e previsto para projetos em Goiás - (FRÖSCH 1958).

$O$ assentamento nos planaltos ligeiramente ondulados na regiáo de Guarapuava $\left(25^{\circ} 30^{\prime}\right.$ lat sul; $3^{\circ}$ planalto), a de 1100 até $1150 \mathrm{~m}$ acima do nível do mar, nos campos limpos subtropicais (cerca de $4.100 \mathrm{~km} 2$ ), que se situam insularmente entre extensas florestas de araucárias, ocorreu na forma de cinco povoados rurais em uma área total de 22.000 ha, sendo aproximadamente $50 \%$ terras aráveis. Como o assentamento nas áreas de colonização no Brasil normalmente é feito em povoamentos 
esparsos distribuídos linearmente, estas povoaçóes foram - com exceção das colônias dos alemães do Volga - as únicas colônias fechadas existentes, porque a segregação espacial de áreas de domicílio e das áreas de cultivo gerava frequientemente problemas de procedimento insolúveis nos estabelecimentos agrários (WAIBEL 1955, PFEIFER 1973). Os suábios do Danúbio, por motivos de ordem sócio-cultural, insistiram, nas povoaçóes rurais, cujo planejamento correspondia às plantas das aldeias da época da colonização do banat que seguiam a "Diretriz Principal de Povoamento" de 1722: estruturação gométrica dos povoados e dos campos, os povoados eram formados de componentes quadrados ou retangulares de mesma área, que, por sua vez, davam ao povoado todo um contorno retangular cercado de malhadas (vide fig.l).

O grupo dos suábios do Danúbio, homogêneo nas suas tradiçóes e metas econômicas, assim como étnica, social e religiosamente (90\% de católicos), deparou-se com um espaço econômico e social em que latifundiários luso-brasileiros, voltados para uma pecuária extensiva e no comércio de mate e madeira, formavam o grupo social dominante. As fazendas, doadas como sesmarias do século XIX, tinham uma extensão média de 13.000 ha (GRUBER DE ABREU, 1981). Apenas por algu-
Fig. 1: Regiño de colonizaç̄oñ " damíbio-suabiar Entre Rios perto de Guarapuava/Parana (planta geral das glebas da Colónia Entre Rios, de acordo com: GAPPMAIER 1987)

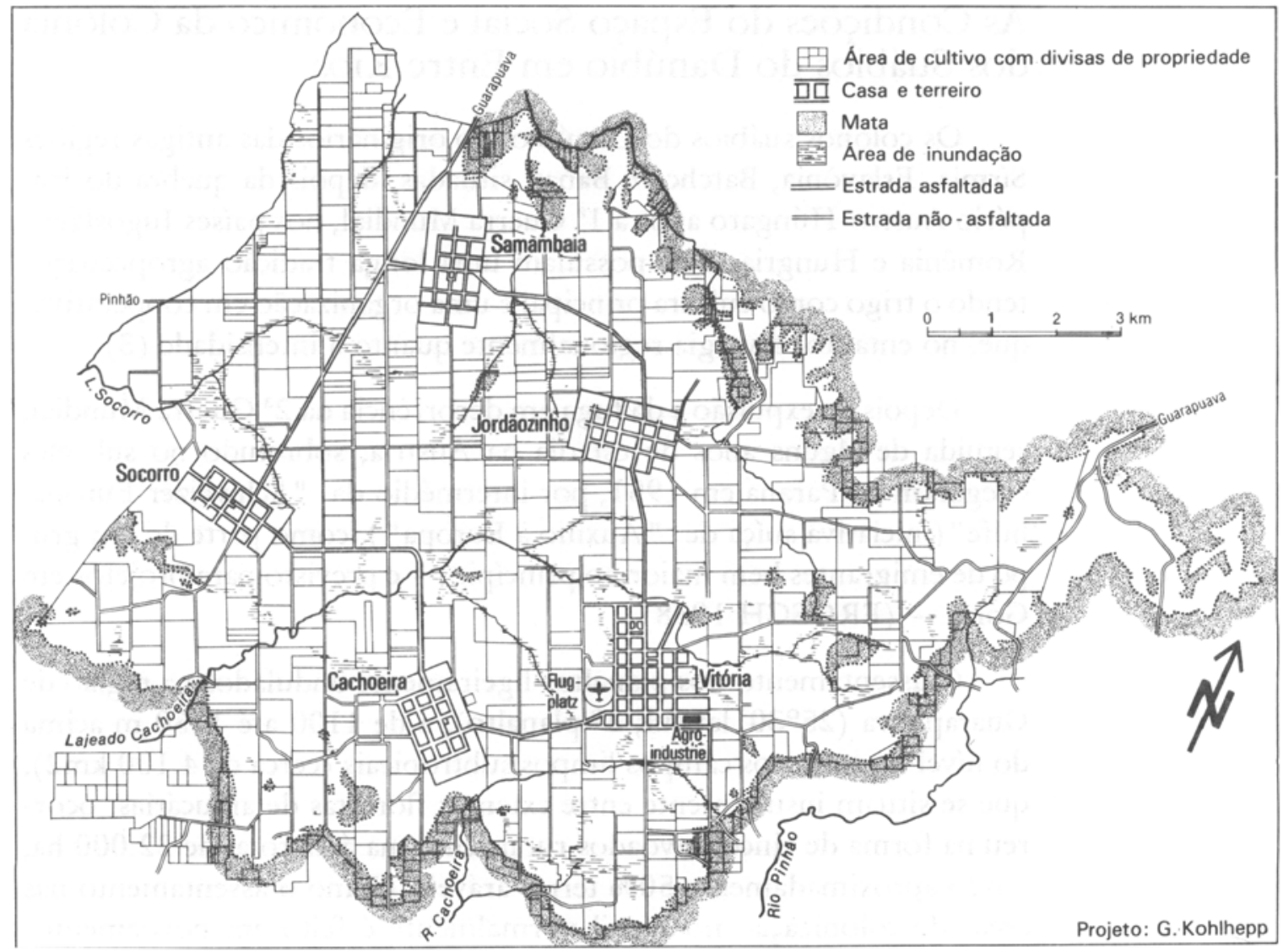


mas décadas na metade do século passado registrou-se algum progresso econômico, originado pelo arrendamento de pastagens naturais para os rebanhos de bovinos e asininos ao longo do caminho de tropas vindo de Cruz Alta (RS), que passava por Palmas e Guarapuava e seguia para Ponta Grossa e São Paulo. Com a decadência dos caminhos de tropas aumentou o "absenteísmo", apenas escravos e capatazes permaneceram nas fazendas estagnadas. A economia de colheita mate e o comércio da araucária tornaram-se as principais fontes de renda (BALHANA 1963, BALHANA/MACHADO 1968). Enquanto alguns fazendeiros alcançaram influência política na capital do Estado, as fazendas isoladas careciam de espírito inovativo e da disponibilidade para novos investimentos e, em parte, faltava também o capital. A cidade de Guarapuava dispunha de um equipamento funcional reduzido até a década de 60 .

Apesar disto a aquisiçáo de terras revelou-se extremamente complicada para os suábios do Danúbio, uma vez que os fazendeiros reagiram com desconfiança aos planos de colonização e aos imigrantes e somente após ameaças de despropriaçáo e adjudicaçáo de terras por parte do governo no norte do Paraná, eles se dispuseram a vender terras. Da mesma maneira o governo viu-se obrigado a reduzir para o nível de preço de mercado os exagerados preços de terra.

Apenas com o desabrochar do sucesso econômico dos suábios do Danúbio os fazendeiros passaram a sacrificar o seu tradicionalismo e o seu orgulho de criadores de gado em razáo de conjunturas econômicas, concretizadas sob forma de lucrativo arrendamento de terras campestres.

O desenvolvimento de Entre Rios na década de $\mathbf{5 0}$ deu-se à sombra dos grandes processos de ocupaçáo de terra no Paraná. O norte do Paraná ia de encontro ao auge do "boom" do café, que também atingira Rolândia, uma colônia alemã mais antiga, composta de refugiados religiosos, políticos e raciais, perseguidos pelo regime nazista (KOHLHEPP 1975). No oeste do Paraná operavam sociedades de colonizaçáo com colonos ítalo e teuto-brasileiros, em parte em colônias etnicamente segregadas, o que se devia ao angariamento seletivo de colonos (KARP 1986). Um processo, aliás, que, em parte, repetiu-se mais tarde no Paraguai oriental (KOHLHEPP 1984a).

Os suábios do Danúbio, registrados pela cooperativa como titulares. legais das povoaçóes, não recorreram à mobilidade espacial em direção às florestas tropicais e subtropicais no norte e noroeste do Paraná, a esta altura envolvidas em processos de ocupaçáo de terra altamente especulativos. Eles estavam voltados unicamente para a colonizaçáo dos campos. Era a remigraçáo para a Alemanha que detinha uma funçáo de válvula para os grandes problemas iniciais, para pressóes econômicas e processos de desalojamento subseqüentes. 


\section{Concentração de Posse e Diferenciação Social como Reação a Pressões de Adaptação Econốmica.}

Em 1953 deu-se o parcelamento da propriedade fundiária individual em Entre Rios, com base no número de pessoas capazes de trabalhar existentes nas respectivas comunidades familiais. Como resultado, a extensão inicial das 323 empresas agropecuárias variava entre 19 a 60 ha e a área cultivável perfazia em média aproximadamente 27 ha.

A decisão de proceder o parcelamento sem considerar a apresentação do relevo e a qualidade do solo, forçada pela insatisfaçáo dos colonos com a administração coletiva inicial, acarretou sérias conseqüências.

A oferta de um ponto de partida idêntico para todos náo só era impossibilitada pelas diferentes extensóes dos lotes de terra correspondentes ao tamanho das famílias, como também o princípio aleatório do sorteio das parcelas na área da colônia levou a consideráveis divergências quanto à qualidade dos solos das empresas que ali surgiram. $O$ erro fundamental foi que condiçóes de solo menos favoráveis não foram compensadas, na partilha, por parcelas maiores.

Tudo isto fez com que as condiçóes iniciais das empresas fossem bastante diferentes e com que o grupo social dos colonos suábios do Danúbio apresentasse, desde o início, uma estrutura heterogênea. A existência de inúmeras empresas mostrou-se desde o início ameaçada, o que gerou insegurança e mobilidade. Isto por sua vez favoreceu a migraçáo e possibilitou, mais tarde, uma consolidação mais rápida da situação econômica dos remanescentes. A migração de famílias rurais na fase inicial até 1954 respondeu, devido aos problemas de adaptaçáo assim como a dificuldades econômicas e organizatórias, por $9 \%$ dos agricultores estabelecidos. Por outro lado, um terço de todas as famílias de artesãos abandonaram Entre Rios neste espaço de tempo, devido à falta de fontes de renda após a fase de construçáo e a dificuldade em erguer empresas independentes.

A extensão média inicial das empresas, de 27 ha, que, porém, ainda superava as extensóes médias das áreas cultivadas na regiăo de origem dos suábios do Danúbio, visava o manejo com animais de tiro e um baixo grau de mecanizaçăo. A meta econômica do cultivo da rotação trigo/arroz sequeiro e a crescente necessidade econômica da mecanização integral trouxe sérios problemas de ordem estrutural para as empresas. Revelou-se como área mínima de cultivo capaz de permitir a agricultura mecanizada uma área de 80 ha, uma vez que o Banco do Brasil estabelecera este valor como limite para o fornecimento de créditos a longo prazo destinados à obtenção de máquinas agrícolas. Também foi demonstrado empiricamente que esta extensão de empresa possibilitava manter um nível de vida satisfatório. 
No início nenhuma das empresas rurais fundadas em 1953 tinha 80 ha de extensão. Pelo contrário, a necessária ampliaçáo das empresas teve que enfrentar, na primeira década, além dos problemas financeiros, a crescente "Realteilung" (partilha em parcelas iguais em caso de herança). Várias empresas operavam à beira ou mesmo abaixo do nível de subsistência, de modo que freqüentemente ocorria o abandono de empresas e o êxodo, que nos anos 60 se concretizava sobretudo na forma da remigração para a Europa, isto é, para a República Federal da Alemanha. Este fato, junto com o abandono de empresas devido ao medo dos encargos financeiros da mecanizaçáo, possibilitou o incremento das empresas remanescentes à base de compra de áreas de estabelecimentos abandonados.

Já em 1950 alguns colonos começaram a arrendar pastagens naturais de fazendeiros nos arredores da colônia Entre Rios e a plantar arroz nestas áreas adicionais, que dava muito bem nos solos ácidos. Os contratos de arrendamento eram fechados freqüentemente por apenas dois ou três anos, já que em seguida as safras se reduziam e se tornaria necessário o emprego de custosos herbicidas para combater as ervas. Deste modo desenvolveu-se um intenso intercâmbio de áreas de arrendamento (GAPPMAIER 1987, p. 78) e boas colheitas de arroz possibilitavam mais arrendamentos.

Nesta fase, na primeira metade dos anos 60 , deu-se uma crescente concentraçáo de posse e uma forte diferenciação social e econômica entre latifundiários (denominado "baróes do arroz" na gíria do colonos) e de minifúndios prejudicados pela "Realteilung". O grupo étnico-social dos suábios do Danúbio foi, pelo crescente potencial de conflitos, levado a uma crise latente, que colocava em perigo a coesáo do grupo.

Os preços de arrendamento, crescendo constantemente, contribuíram ainda mais para agravar as disparidades. Os fazendeiros dos campos de Guarapuava aproveitavam-se do sucesso econômico dos latifúndios para valorizar suas terras, até então apenas aproveitadas de modo bastante extensivo em capital. Aos conflitos de interesse internos da colônia juntaram-se os conflitos externos com os proprietários de terra. $\mathrm{O}$ aumento dos preços de terra e de arrendamento prejudicava o imprescindível incremento espacial das áreas de cultivo e levava a processos de segregação social em Entre Rios. Enquanto os latifúndios podiam, devido a máquinas e sobretudo caminhóes já existentes, arrendar terras cada vez mais distantes (até mais ou menos $100 \mathrm{~km}$ ) de Entre Rios e que eram, em parte, trabalhadas por mão-de-obra contratada; o "anel" de terras já ocupadas, que se estendia de forma quase circular ao redor da colônia, assim como altos preços nos arredores, "estrangulavam" a expansão das pequenas empresas, que dependiam da infra-estrutura ofe- 
recida pela cooperativa central em Entre Rios (4). Ao mesmo tempo aumentava o desmembramento de posses através da "Realteilung". De 1963 a 1967 a parcela das empresas com menos de 20 ha cresceu de $27,4 \%$ a $51,7 \%$. A parcela das empresas que operam acima do limite econômico de 80 ha caiu de 10,5\% para 7,1\%, de modo que em 1967 apenas 27 colonos possuíam mais de 80 ha (KOHLHEPP 1969).

Nesta fase crítica o êxodo era especialmente forte. Até 1971 um total de 1.776 pessoas abandonou a colônia (284 famílias e mais $\mathbf{8 0}$ membros de outras famílias) (ELFES 1971, GAPPMAIER 1987).

Uma reorientação fundamental do cooperativismo, que esteve ligada à tomada da diretoria da cooperativa central por colonos jovens $\mathrm{e}$ resolutos (cf. cap. 7), levou ao início do progresso decisivo para os colonos remanescentes.

Depois que, através de melhoramentos fundamentais, foram fechadas as lacunas no setor educativo a nível escolar, foi possível criar, através de uma nova concepção na aquisiçăo de terras, as condiçóes econômicas que finalmente, no início dos anos 70 , conseguiram interromper o êxodo, que quase levara ao colapso sócio-cultural.

Atividades da Cooperativa com Efeito Espacial: Projetos da Terra, Reforma Agrária Interna, Consolidação da Estrutura Empresarial, Estabilização do Assentamento Central

A escassez de terra da maioria das empresas agropecuárias, que entrementes havia assumido proporçóes graves, foi solucionada por medidas em duas etapas. Estas medidas visavam, por um lado, a criação de projetos de terra com base na compra de terras além das delimitaçóes da colônia. Por outro lado, no entanto, esta ação desencadeou uma reforma agrária interna, ou melhor, uma espécie de remembramento fundiário, em que os candidatos à concessáo de terras nos projetos recém-criados sobretudo agricultores jovens - tinham que transferir suas terras (desde que não ultrapassassem os $\mathbf{5 0}$ ha) situadas dentro dos limites da colônia à cooperativa, que, por sua vez, as utilizou para arredondar os terrenos de outras empresas. Isto aconteceu sobretudo naqueles povoados que, devido a um êxodo reduzido, apresentavam as menores áreas de cultivo (Jordáozinho, Samambaia). Os projetos, sustentados por um fundo de terras da cooperativa e em parte também pelos bancos, serviam para instalar estabelecimentos economicamente lucrativos para aquelas famílias que não dispunham de capital para a compra de terras. Os "colonos dos projetos", no entanto, estavam submetidos a rígidos encargos no que se refere ao emprego e à restituição dos créditos, cujos vencimentos eram de 12 anos, e tinham que atender aos conselhos agrotécnicos da cooperativa, que também controlava todas as atividades empresariais. 


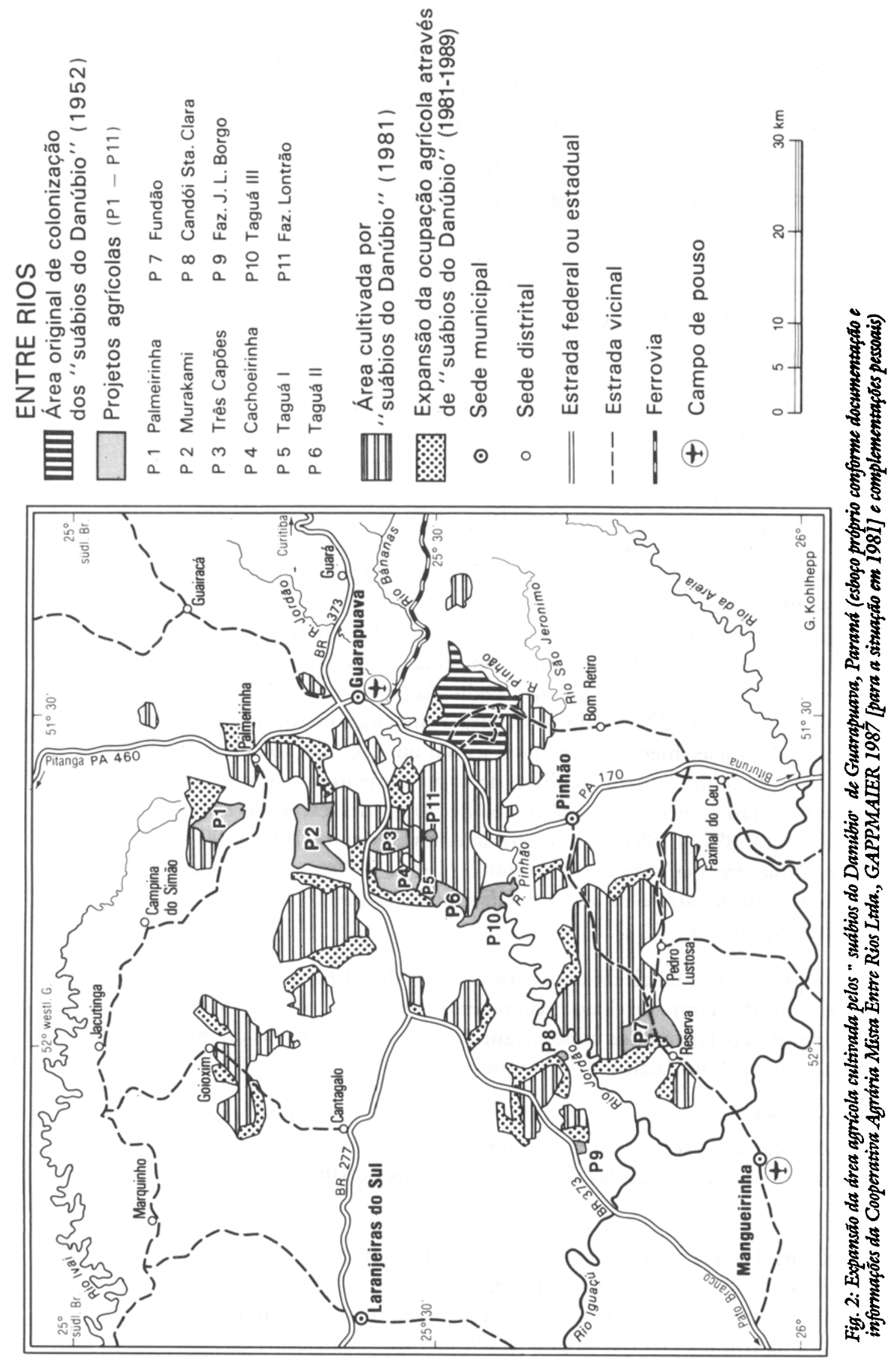

EstudOS AvaNÇADOS 11(5), 1991 
Ao todo, 165 membros da cooperativa puderam tirar proveito dos 11 projetos de terra (vide fig. 2) instalados entre 1967 e 1982, sendo que foram adquiridos adicionalmente 12.580 ha de terra e redistribuídos 1.620 ha dentro das delimitaçóes oficiais da colônia.

A ação dirigida pela cooperativa fez com que fosse eliminada a situaçáo de concorrência, dada à geraçáo de conflitos, em que se encontrariam os supostos compradores de terra suábios do Danúbio, e que os fazendeiros tivessem que enfrentar uma organização de situação financeira sólida e também com uma base de negociaçôes forte, que procurava pressionar a faixa de preços dos vendedores de terra, mas que, por outro lado, também operava como parceiro de confiança. Devido às modalidades de pagamento favoráveis para o vendedor de terra, era espacialmente em casos de herança nas fazendas da vizinhança que o interesse pela venda de terras crescia, e com isso tornava-se possível incrementar a área de cultivo e a parcela de terrenos próprios dos suábios do Danúbio.

O aumento de tamanho dos estabelecimentos reflete claramente a tendência para o surgimento de empresas médias e grandes. $O$ processo de concentraçáo por deslocamenteo, que levou a uma reduçáo de quase $50 \%$ do número total de estabelecimentos agrícolas de 381 para 196 entre 1964 a 1978, deu lugar a uma consolidação. Nos anos 80 o número de famílias suábio-danubianas dedicadas à agropecuária equilibrou-se em torno de 220. A fig. 4 mostra a mudança estrutural na extensáo dos estabelecimentos, que ainda sofreu uma aceleração depois de 1972, quando se introduziu o cultivo de soja altamente mecanizado. $O$ estrato de estabelecimentos com menos de 50 ha decresceu de $87,4 \%$ (1964) para 9,8\% (1988). O número de empresas entre 100 e 500 ha domina hoje em dia com cerca de 60\% (1964: 4,7\%), sendo que a participação deste estrato na área total dos estabelecimento, $52 \%$, reflete um certo equilíbrio.

Enquanto os estabelecimentos com menos de $\mathbf{5 0}$ ha são exclusivamente mantidos como atividade secundária e, em parte, arrendados internamente, sete latifúndios concentram $23 \%$ da área das terras em propriedade dos colonos suábios do Danúbio.

Incluindo-se as terras arrendadas, é possível formular afirmativas mais diferenciadas sobre a área trabalhada pelas empresas. Nota-se especialmente que a parcela das empresas com mais de 100 ha cresce para $74 \%$.

Já em 1965 a parcela das terras arrendadas fora de Entre Rios, considerando ser a área total das propriedades de 25.722 ha, era, com $\mathbf{2 7 , 5 \%}$, quase igual à parcela das áreas recém-compradas além das delimitaçôes da colônia (KOHLHEPP 1969, p. 143). A área dos estabele- 


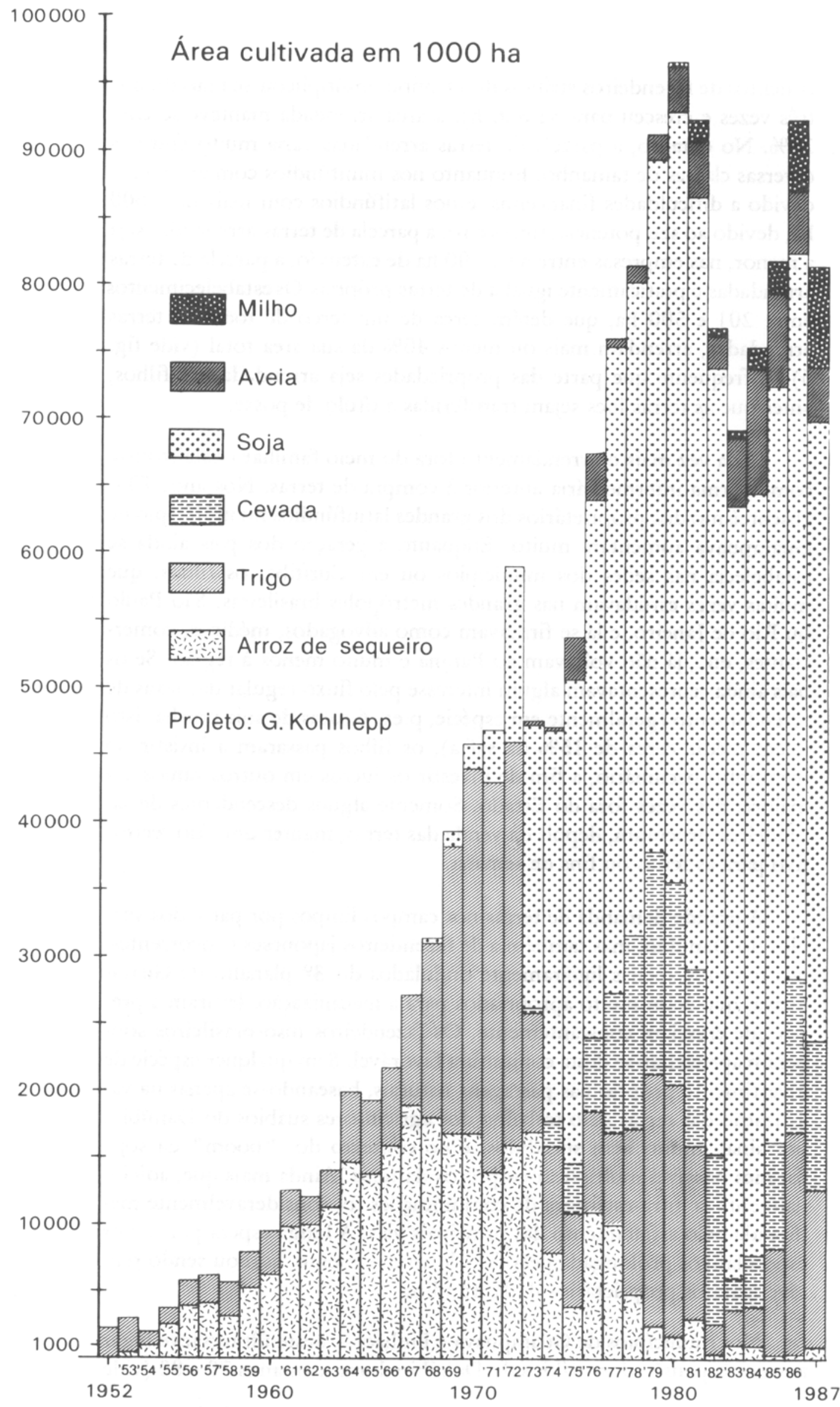

Fig. 3: Desenvolvimento do uso da terra em Entre Rios 1952 - 1987 (conforme dados estatísticos da Coop. Agrária Mista Entre Rios Ltda.) 
cimentos de fazendeiros suábios do Danúbio multiplicou-se mais do que três vezes e cresceu para 81.300 ha, a área arrendada manteve-se com $28 \%$. No entanto, a parcela de terras arrendadas varia muito entre as diversas classes de tamanho. Enquanto nos minifúndios com até $\mathbf{5 0}$ ha, devido a dificuldades financeiras, e nos latifúndios com mais de $\mathbf{2 . 0 0 0}$ ha, devido ao seu potencial financeiro, a parcela de terras arrendadas seja a menor, nas empresas entre 51 e 100 ha de extensáo, a parcela de terras arrendadas é praticamente igual à de terras próprias. Os estabelecimentos entre 201 e 500 ha, que detém cerca de um terço de todas as terras arrendadas, arrendam mais ou menos $40 \%$ da sua área total (vide fig. 6). É freqüente que parte das propriedades seja arrendada aos filhos, antes que as terras lhes sejam transferidas a título de posse.

Cada vez mais o arrendamento fora do meio familiar cristalizou-se como forma intermediária anterior à compra de terras. Nos anos 700 absenteísmo dos proprietários dos grandes latinfúndios no município de Guarapuava aumentara muito. Enquanto a geraçáo dos pais ainda se estabelecia nas sedes dos municípios ou em Curitiba, os filhos, que muitas vezes estudavam nas grandes metrópoles brasileiras, São Paulo ou Rio de Janeiro, e lá se firmavam como advogados, médicos, comerciantes, etc., já náo voltavam ao Paraná e muito menos à região. Se os pais ainda representavam algum interesse pelo fluxo regular das taxas de arrendamento (geralmente em espécie, p.ex. 6 sacas de soja por ha, isto é, em média cerca de $15 \%$ da safra), os filhos passaram a insistir no reembolso pecuniário, a fim de investir os lucros em outros ramos, na maioria das vezes fora do Estado. Somente alguns descendentes de fazendeiros procuram, depois da venda das terras, manter um sítio recreativo para as férias ou fins de semana.

A grande demanda de terras nos campos limpos por parte dos suábios do Danúbio, mas também a de fazendeiros japoneses concorrentes, nos terrenos apenas ligeiramente ondulados do $3 \%$ planalto de Guarapuava, que eram muito apropriados para a mecanização, levaram a preços que cresciam constantemente. Os fazendeiros luso-brasileiros souberam aproveitar-se desta conjuntura favorável. Sem qualquer espécie de investimento próprio nas pastagens naturais, baseando-se apenas na valorização das terras pelo trabalho dos agricultores suábios do Danúbio, por sinal, muito bem sucedidos, e no contexto do "boom" da soja, foi-lhes possível multiplicar os preços da terra. Ainda mais que, adicionalmente, a infra-estrutura de comunicações foi consideravelmente melhorada pelo asfaltamento das principais vias. A longa espera por lucros especulativos prolongada pela fase de arrendamento, acabou sendo rentável para os proprietários de latifúndios.

Nos municípios de Guarapuava e Pinhão - neste último teve lugar a maior expansão dos suábios do Danúbio durante os anos 70 e 80 (vide 
fig. 2) - já não é possível adquirir terras de campo por menos de 1.000 dólares por ha. As terras nas áreas de arredondamento de grandes propriedades são mais valiosas ainda. Os preços por ha nas redondezas dos povoados de Entre Rios atingiram mesmo os 3.000 dólares (1951: 25 a 30 dólares) e estáo entre os mais altos nas regiōes rurais brasileiras.

É altamente interessante observar, e ressalta bem a mentalidade apegada à terra dos suábios do Danúbio, que a cooperativa em Entre Rios afastou todas as conjeturas de compra de terras e abertura de entrepostos nas novas zonas pioneiras, como p.ex. no norte ou no oeste do Paraná, ou, mais tarde, no Mato Grosso do Sul. Com isto pretendia-se não só evitar o êxodo, mas também reforçar a base sócio-cultural da área central de povoamento. Deste modo alguns jovens agricultores, que haviam se radicado em Mato Grosso do Sul por algum tempo, regressaram ao "seio" da comunidade suábio-danubiana, que hoje se acha fortalecida e consolidada pela atenuação das mais graves disparidades sociais no grupo étnico-social. Isto também vale para os estudantes que fizeram cursos agrotécnicos ou mesmo cursos universitários, que hoje em oposição ao êxodo rural largamente divulgado - voltam para Entre Rios. Para garantir a coesão do grupo fora da colônia foi instalada uma casa de estudantes em Curitiba.

Em vista do "tamanho crítico" da atual população e das taxas de natalidade relativamente baixas é da maior importância assegurar uma existência econômica para a juventude, preservando os laços sociais existentes e criando ofertas culturais de aceitação local. Neste sentido foi elaborada uma estratégia prudente pela cooperativa (vide cap. 7).

Apesar da extraordinária extensão das áreas trabalhadas (vide fig. 2) foi reprovada a idéia de fundaçáo de um novo povoado, para não enfraquecer os cinco povoados na regiáo central de Entre Rios, o que poderia, sobretudo para Socorro e, em parte, para Jordáozinho, ter-se tornado uma ameaça à existência.

As empresas médias maiores e os grandes estabelecimentos, que hoje dispóem sobre um considerável parque de máquinas e ocupam mão-de-obra contratada, já instalaram há tempos depósitos de máquinas, armazéns, casas para os trabalhadores rurais e, em parte, pequenas residências para os proprietários, utilizadas em épocas de trabalho máximo, nas suas lavouras distantes, que, às vezes, ficam a mais de $100 \mathrm{~km}$ dos povoados. Durante as semeadas e nas épocas de safra até mesmo os proprietários transformam-se em pessoas que vêm e vão nos fins-de-semana. Devido ao grande conforto dos fazendeiros em Entre Rios hoje em dia e à infra-estrutura dos povoados, sobretudo na vila principal, Vitória, nenhum dos proprietários está interessado em uma mudança de residência para fora. Isto fortalece os laços sociais dentro das comunida- 
des rurais e as bases sócio-culturais do suábios do Danúbio como grupo étnico.

Apenas a sudoeste de Pinhão a cooperativa - devido às más condiçóes rodoviárias - fez erguer um depósito para o armazenamento da safra assim como de adubos, inseticidas e pesticidas, para avaliar os seus associados no que se refere à duração e aos custos do transporte para Vitória.

\section{Ciclos de Desenvolvimento Agroeconômico}

A evolução da agricultura em Entre Rios e, com isto, as bases econômicas de existência dos suábios do Danúbio foram, desde 1952, marcadas por diversos ciclos econômicos, que se fizeram notar em sucessóes no uso da terra ou como mudanças dos sistemas empresariais agropecuários.

A inovação básica realizada pelos suábios do Danúbio foi o início do aproveitamento agrícola dos campos limpos. Já na fase inicial ocorreu uma rápida reorientaçáo do arado com animais de tração, que lhes era familiar nas suas regiốes de origem, para uma agropecuária mecanizada, mais adequada para os terrenos maiores. A função triticultora, que lhes foi atribuída inicialmente e de cuja atividade inovadora esperava-se um efeito de difusáo para o Paraná, só pôde ser cumprida de maneira rudimentar, devido a diversos problemas com as condiçōes de relevo e climáticas desconhecidas.

Depois de uma curta fase experimental, no entanto, e já a partir de 1955, o cultivo de arroz sequeiro tornou-se o fator econômico decisivo até à $2^{\mathrm{a}}$ metade dos anos 60 (vide fig. 3 ). Com investimentos relativamente baixos iniciou-se, sobretudo através do arrendamento adicional de pastagens naturais, o cultivo de arroz sequeiro em larga escala. $\mathrm{Na}$ segunda metade dos anos 60 o cultivo de arroz foi decaindo lentamente, devido à reduzida disponibilidade de campos naturais e à concorrência de agricultores japoneses, cultivadores de batata, no arrendamento. Mais tarde, com a ascensão da soja como cultura de veráo predominante e bem mais atrativa quanto ao preço, o cultivo do arroz foi completamente reprimido.

Antes do "boom" da soja, porém, fora a triticultura que marcou a $2^{a}$ fase de desenvolvimento em Entre Rios. Este desenvolvimento tem que ser visto no contexto da modernização da agropecuária brasileria, subvencionada pelo governo (KOHLHEPP 1989), no âmbito das novas metas agropolíticas do governo militar a partir de 1964, assim como de conjunturas político comerciais. A triticultura recebeu prioridade, pois visava-se reduzir as elevadas importaçôes de trigo, que pesavam 


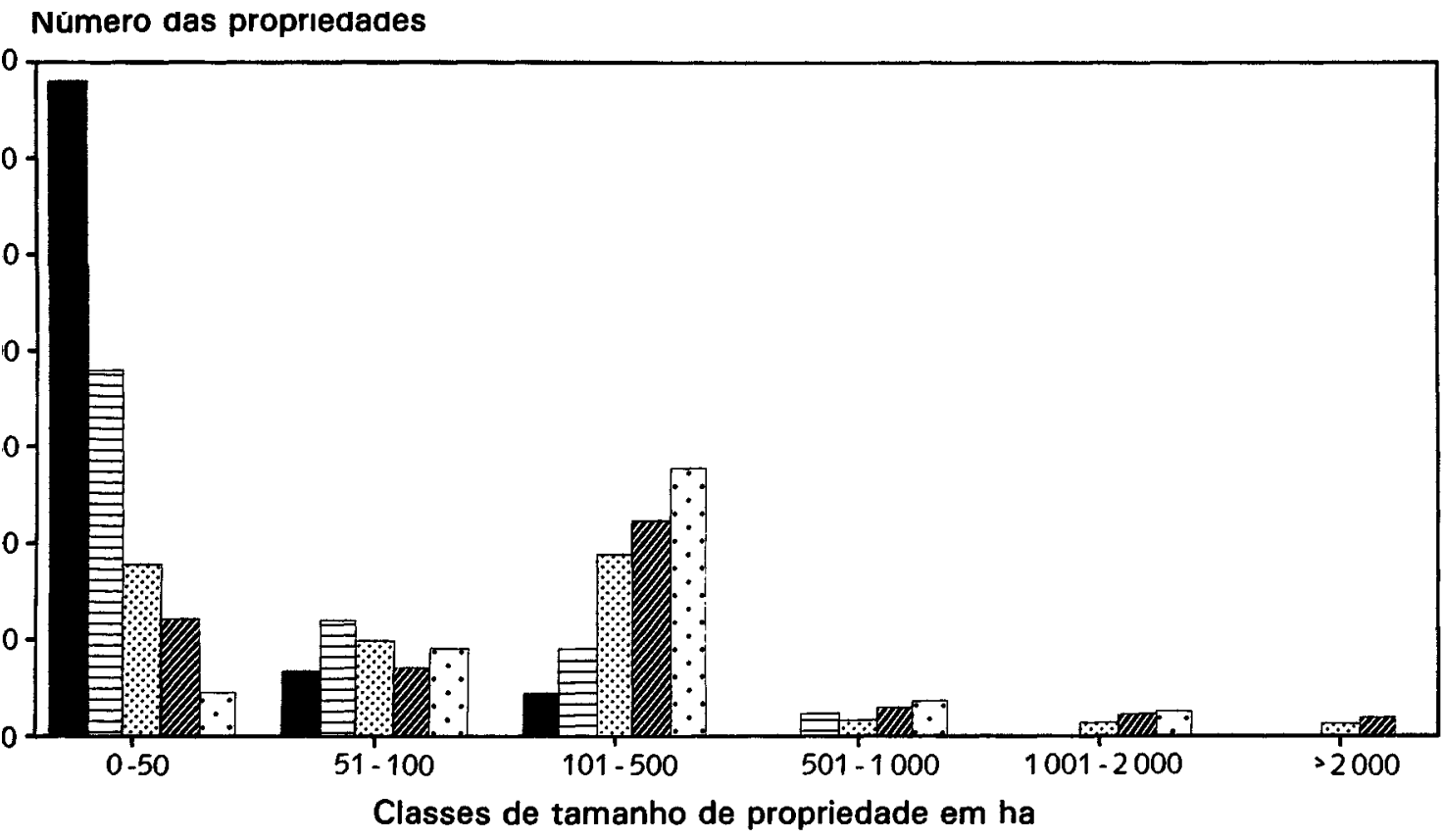

1964
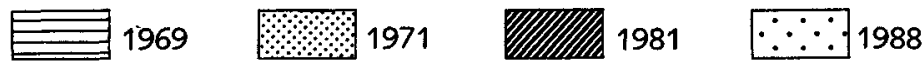

Projeto: G. Kohlhepp

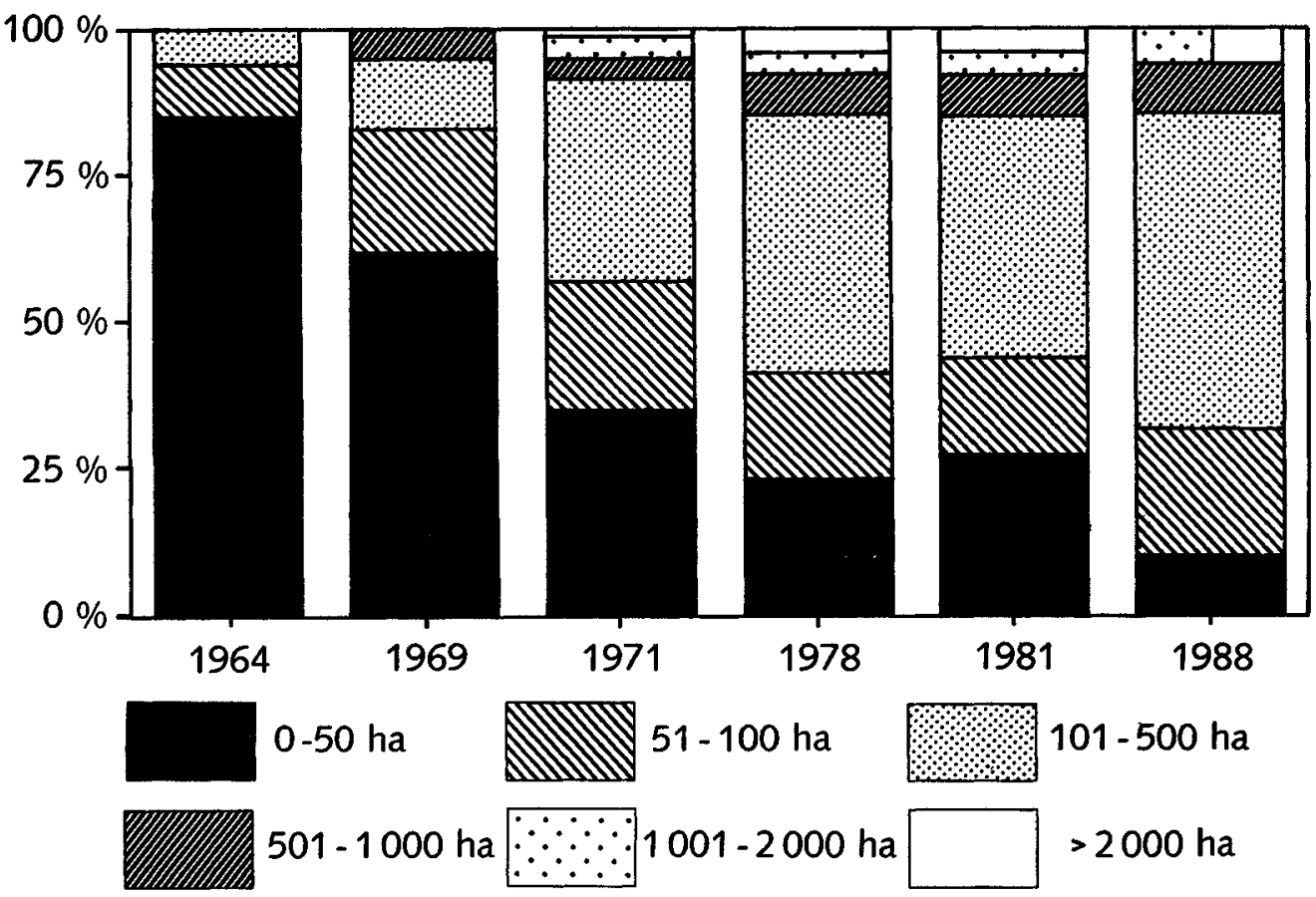

Projeto: G. Kohlhepp

7ig. 4: Nimero e percentual das propriedades agricolas de acordo com classes de tamanbo de propriedade [terra propria] 1964 - 1988 (fontes: vide fig. 3 e GAPPMAEIR 1987) 


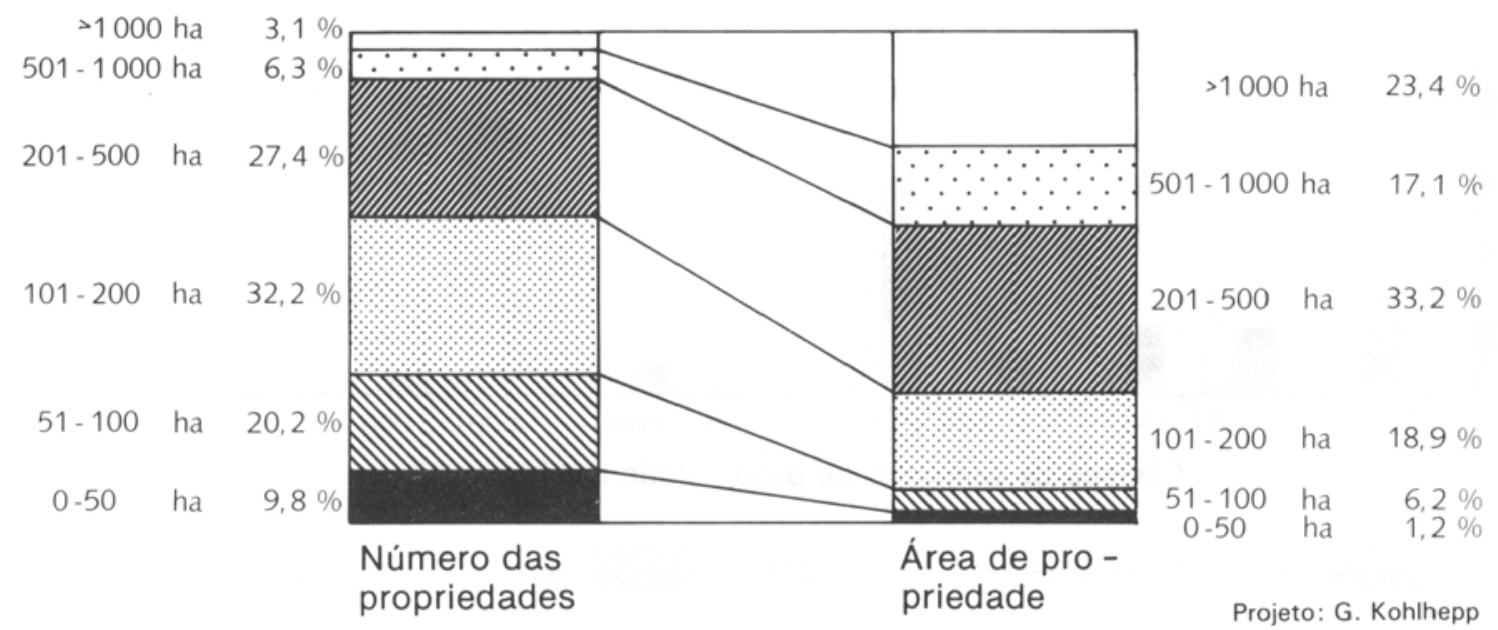

Fig. 5: Número e área das propriedades [terra própria] segundo as classes de tamanho 1988 (fontes: vide fig. 3 e A. Gora 1988, Entre Rios)

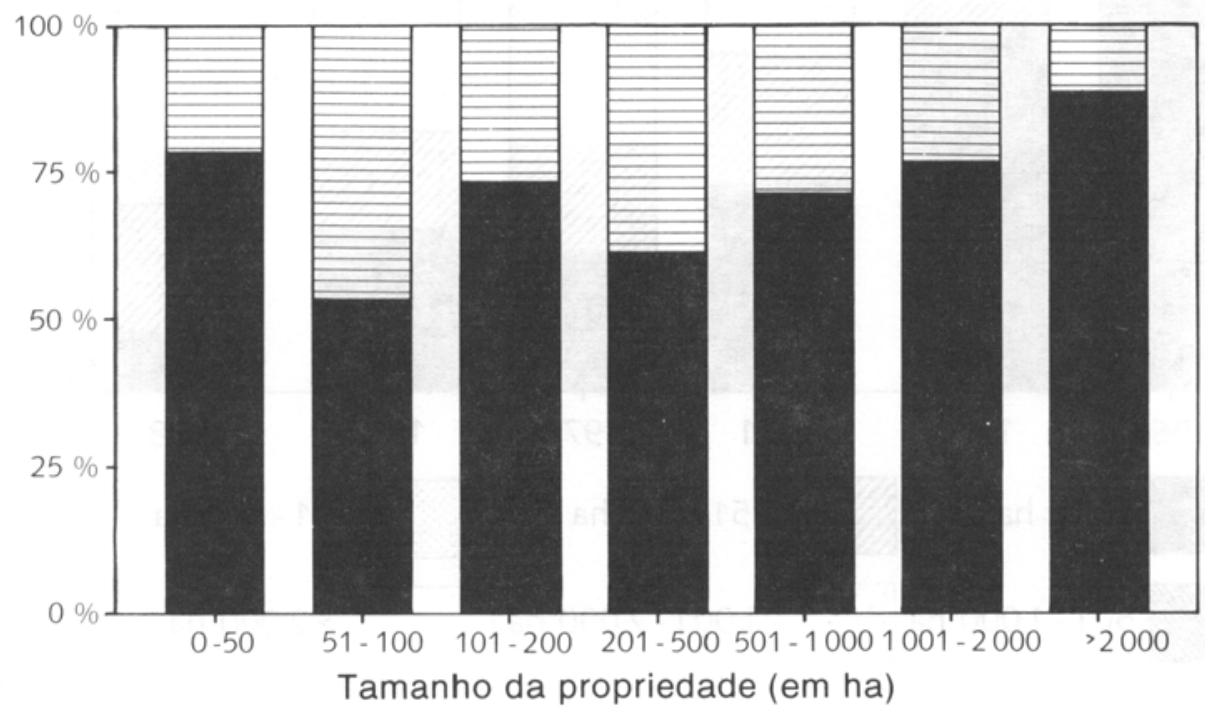

Terra própria

Terra de parceria

Fig. 6: Percentual de terra própria e terra de parceria no que concerne a cooperativas agricolas 1981 (fontes: vide fig $3 e$ GAPPMAIER 1987, tab. 18) 
muito na balança comercial brasileira depois da primeira crise do petróleo. Preços mínimos garantidos e condiçōes de crédito favoráveis, que possibilitavam a compra de adubos e a mecanizaçáo, exerciam uma forte atraçăo. Em adição veio o desenvolvimento de espécies que garantiam um bom rendimento, uma vez que eram resistentes à ferrugem. Como fatores favoráveis adicionais e específicos da região atuaram a reorganização esquemática da cooperativa central em Entre Rios, assim como o esforço, finalmente coroado de êxito, para obter auxílios ao desenvolvimento de parte da República Federal da Alemanha (KOHLHEPP 1969, pp. 145/46). Pela importaçăo isenta de direitos alfandegários de adubos químicos, de herbicidas e máquinas agrícolas (sobretudo ceifeiras) em 1968, pela instalaçăo de um atendimento técnico agropecuário dirigido, assim como por uma série de experiências efetuadas por cientistas alemães, foram tomadas as iniciativas decisivas para uma consolidação de Entre Rios. A cooperativa pôde, através da venda de adubos e máquinas, erguer uma sólida base financeira para - com solvência aumentada junto aos bancos brasileiros - poder levar para frente com êxito o programa de reformas iniciado.

Entre 1966 e 1972 foi quintuplicada a área de cultivo de trigo (vide fig. 3), os rendimentos por hectare alcançaram, pela primeira vez, os $1500 \mathrm{~kg} / \mathrm{ha}$ (vide fig. 9) e, após este evento, que até mesmo na Alemanha foi festejado como "o milagre do trigo" no Paraná (WIELAND 1969), Entre Rios tornou-se um dos produtores de trigo mais importantes do Brasil.

Em 1972 geadas violentas em fins de setembro levaram não só a uma safra catastrófica (vide fig. 7), com também a um colapso instantâneo do "boom"do trigo, que foi então, em 1973, substituído pela terceira fase, pelo cultivo de soja. O medo destas geadas no fim do inverno e da alta umidade atmosférica fez com que nos anos seguintes, apesar dos incentivos governamentais, a triticultura nunca mais pudesse se recuperar integralmente.

Se os rizicultores já haviam sido incentivados pelo trigo, com cultura de inverno, a comprar as terras arrendadas, a fim de poder efetuar uma rotação de culturas regular, agora então tornou-se possivel uma rotação trigo/soja, que, no entanto, mostrou-se problemática de início, devido à quebra do "boom" do trigo e pela falta de alternativas para a semeada de inverno.

A partir de 1972 o cultivo de soja presenciou, com bons preços, uma extraordinária expansão (vide fig. 3 ; 1971: 3.900 ha; 1977: 48.000 ha; 1982: $58.650 \mathrm{ha}$ ), sendo que, no entanto, a produtividade náo pôde ser aumentada consideravelmente. Mas devido ao aumento das áreas de cultivo foi possível obter uma produçáo de mais ou menos $100.000 \mathrm{t}$ pela primeira vez em 1981. Nos anos 70 e na primeira metade dos anos 

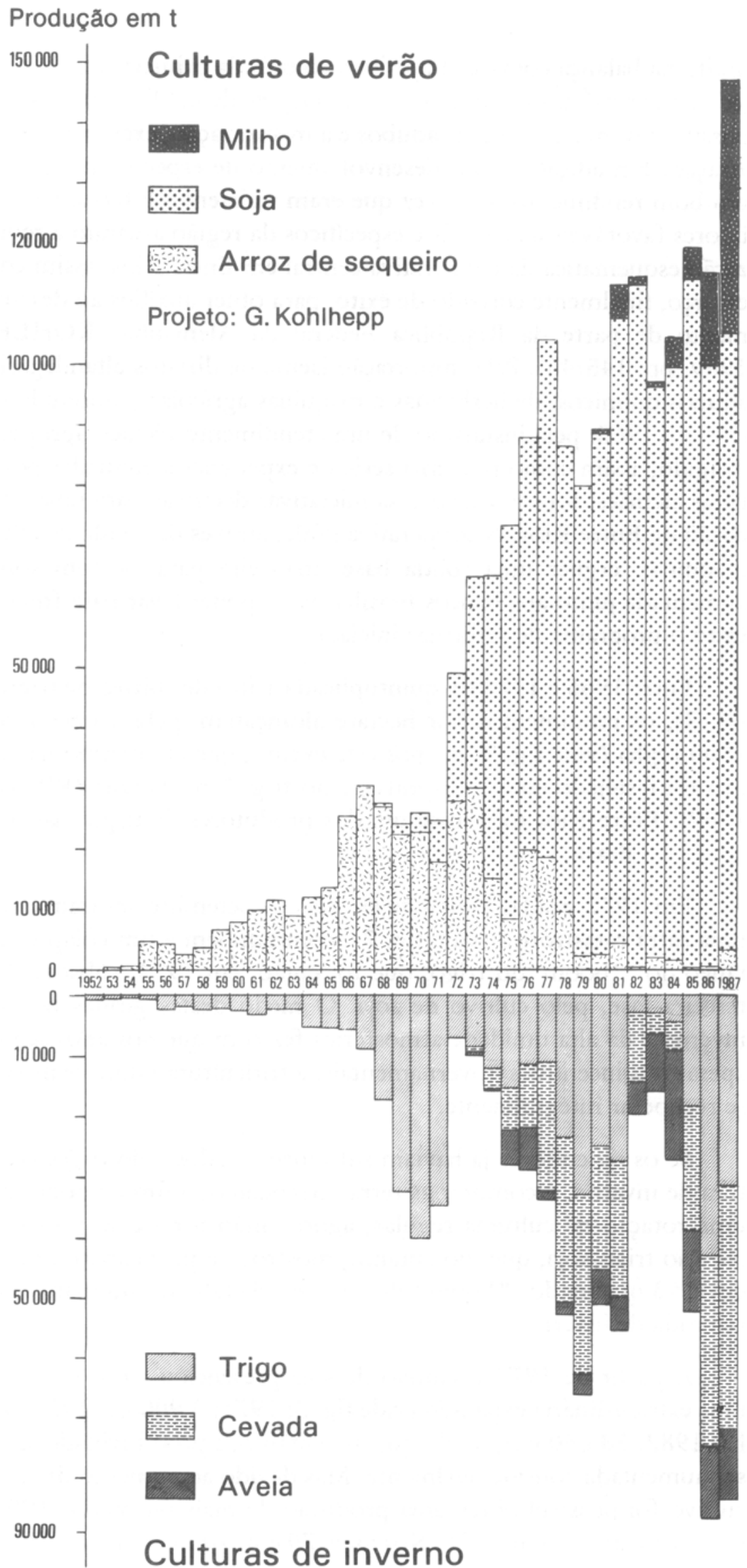

Fig. 7: Evoluf̧ão da produção de culturas de verão e inverno em Entre Rios (fonte: vide fig. 3) 
80 a soja mantém-se como cultura principal, superando todas as outras, em Entre Rios - aliás, como em muitas regióes do Sul e do CentroOeste nesta fase - ocasionando uma orientaçáo agrícola quase que monocultora. Isto gerou uma crescente dependência dos preços de soja no mercado mundial e um aumento da predisposiçáo a crises.

Nos últimos anos, através de um aumento considerável do cultivo de milho - aproveitando-se de espécies altamente lucrativas, assim como de bons preços e das saídas garantidas no mercado de forragens -, foi iniciada uma reduçáo do risco econômico nas culturas de verão (vide figs. 3 e 7). No âmbito das culturas de inverno isto já é bem mais difícil. $\mathrm{Na}$ triticultura permanecem as grandes oscilaçóes na rentabilidade e os bons rendimentos em 1986 e 1987 devem ser atribuídos a uma temporada relativamente seca, que garantiu um bom retorno mesmo àquelas empresas que, por motivos financeiros, só podem fazér pouco uso de agentes químicos de combate à ferrugem. $\mathrm{O}$ cultivo da aveia não pode ser ampliado no momento, pois o mercado, composto de um único comprador, é reduzido.

Devido à adoçáo de um sistema de plantio direto para evitar a erosão do solo, elaborado cientificamente e com bons resultados em um projeto da GTZ (Sociedade Alemã de Cooperação Técnica) no norte do Paraná (vide KOHLHEPP 1989), hoje em dia 90\% das terras de culturas de veráo (soja, milho) são tratadas com métodos específicos e adaptados ao local, o que traz vantagens agrotécnicas, econômicas e ecológicas, mas exige conhecimentos agrotécnicos profundos e geram um aumento dos custos. As culturas de inverno, porém, ainda são problemáticas, pois parece que elas, usando-se o plantio direto, mostram-se mais ameaçadas pela geada (5).

\section{A Inovação do Cultivo de Cevada e Difusão no Sul do Brasil}

No âmbito dos constantes esforços no sentido de diversificar as culturas de inverno, que se destinam a reduzir o risco econômico e a evitar danos de erosão nas terras em pousio, já se começou, em 1973, com o cultivo de cevada em Entre Rios. Por razóes climáticas, a cevada só pode ser cultivada nos três Estados sulistas, onde, entre altitudes entre 800 e $1200 \mathrm{~m}$, as temperaturas médias mensais estáo abaixo de $17^{\circ} \mathrm{C}$ de maio a outubro e existem precipitaçóes razoáveis no inverno, bem como um ciclo vegetativo de 115 a 120 dias; propiciando-se assim boas condiçóes para o cultivo. Se as temperaturas médias excedem este valor o grau de albumina na cevada ultrapassa os $12 \%$ permitidos na maltagem.

A iniciativa da cooperativa agrária baseava-se na demanda de malte 


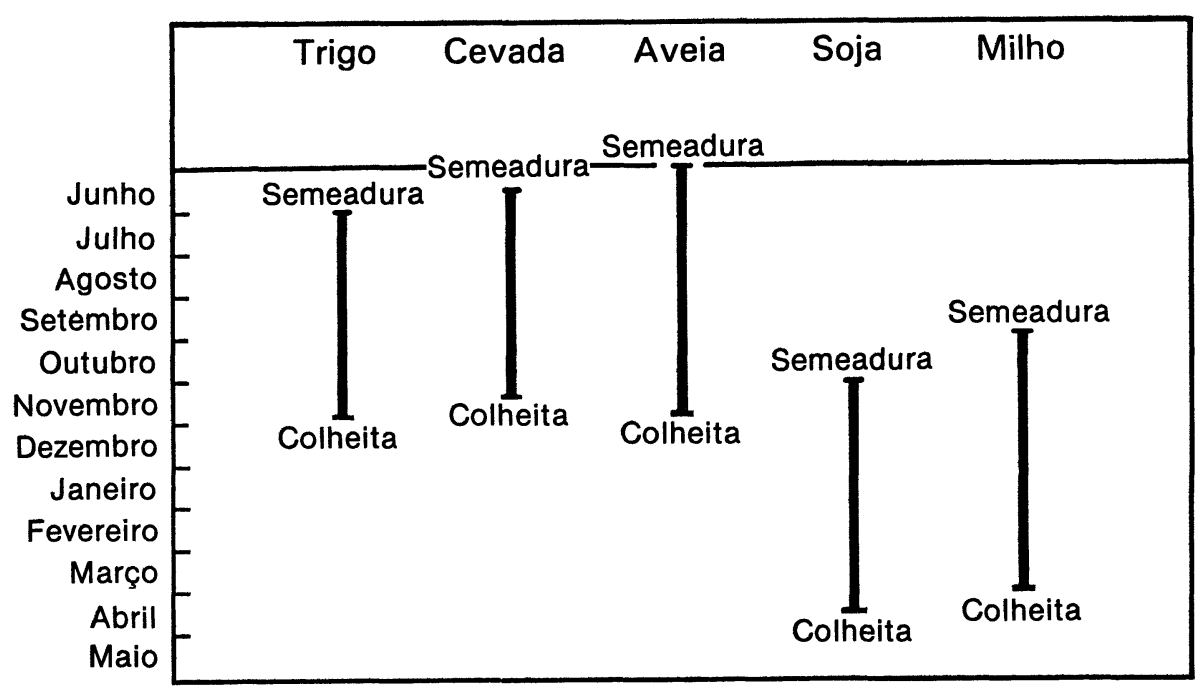

Projeto: G. Kohlhepp
Fig. 8: Épocas semeadura e colloeita dos principais produtos agricolas em Entre Rios (conforme informafốes de $A$. Gora, Entre Rios, 1988)

da indústria cervejeira do Brasil, que tinha que ser coberta quase que inteiramente por importaçóes. Já em 1975 Entre Rios alcançou 15,5\% da área de cultivo e $27,7 \%$ da produçáo de cevado do Brasil. Em vista do crescente consumo de cerveja no Brasil, que se duplicava a cada 5 anos na década de 70 e no início dos anos 80 , e a fim de cumprir a meta econômica de aumentar a produção própria e de melhorar a situação da balança comercial, a produçáo de cevada e de malte recebeu subsídios governamentais. Graças aos contatos da cooperativa suábio-danubiana com o segundo maior produtor de cerveja do país, a Cia. Antártica Paulista, cuja unidade de maltagem comprava a safra de cevada de Entre

\section{Entre Rios/PARANÁ produtividade}

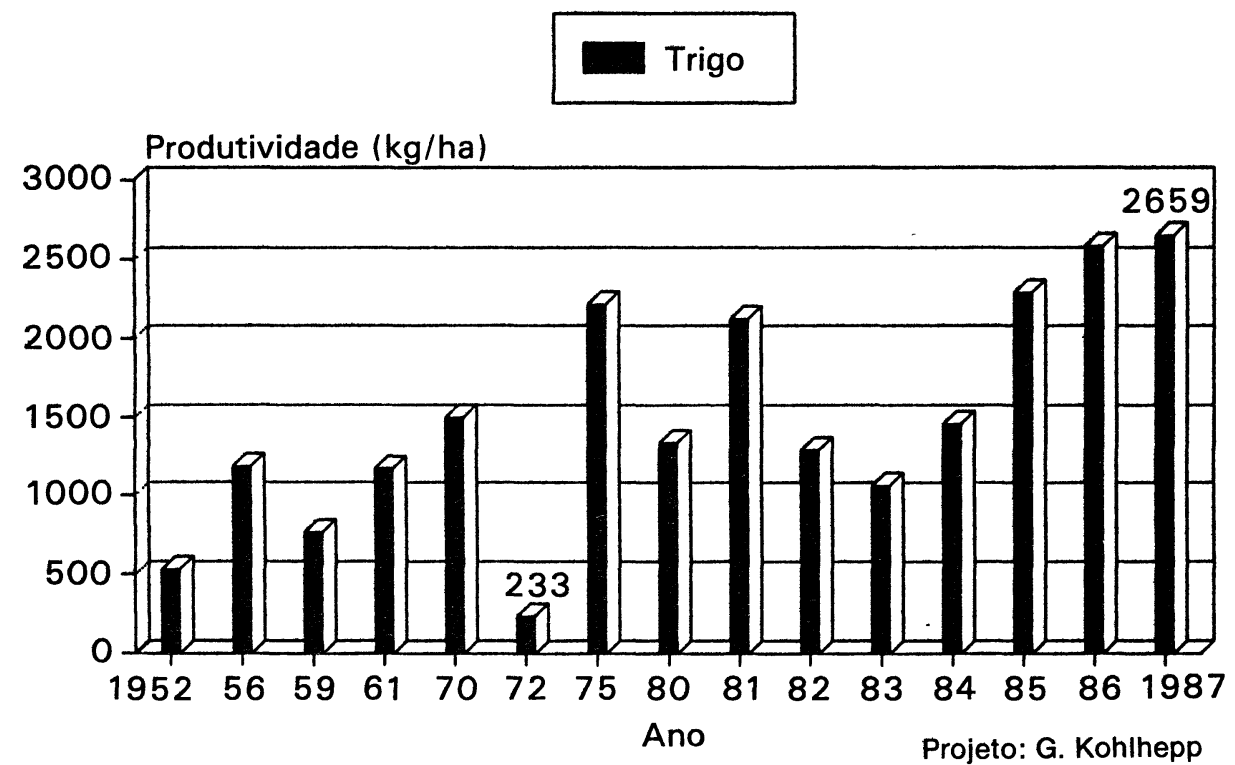

Fig. 9: Evolução da produtividade do trigo em Entre Rios (fonte: vide fig. 3) 
Rios na década de 70, e à rápida expansão do cultivo de cevada nos arredores de Entre Rios, surgiu o projeto comum (Agromalte S. A.) de uma unidade de maltagem na regiáo produtora, localizada em Vitória/Entre Rios. Neste ínterim os suábios do Danúbio haviam se tornado os maiores produtores de cevada do Brasil e Entre Rios apresentava uma infra-estrutura técnica bem desenvolvida.

Em fins de 1981 a unidade de maltagem iniciou suas atividades com uma capacidade de processamento de $60.000 \mathrm{t}$ de cerveja, ou seja, uma produção anual de $53.000 \mathrm{t}$ de malte. Em 1988 foram produzidos $76.000 \mathrm{t}$ de malte, o que corresponde a pouco mais de $100.000 \mathrm{t}$ de cevada, das quais $60 \%$ foram compradas de fora, na base de contratos de fornecimento. A unidade de maltagem, que desde 1989 se encontra somente em mãos da cooperativa suábio-danubiana, é hoje a maior da América do Sul.

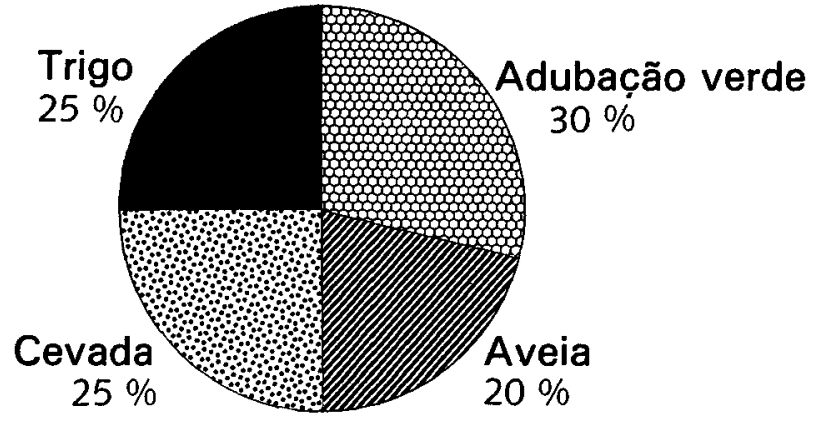

Produtos de inverno (I)

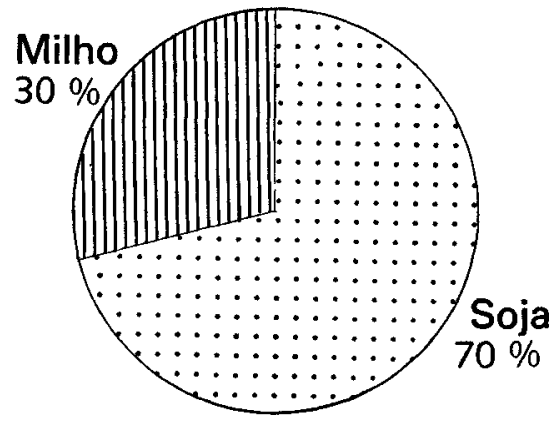

Produtos de verão (V)

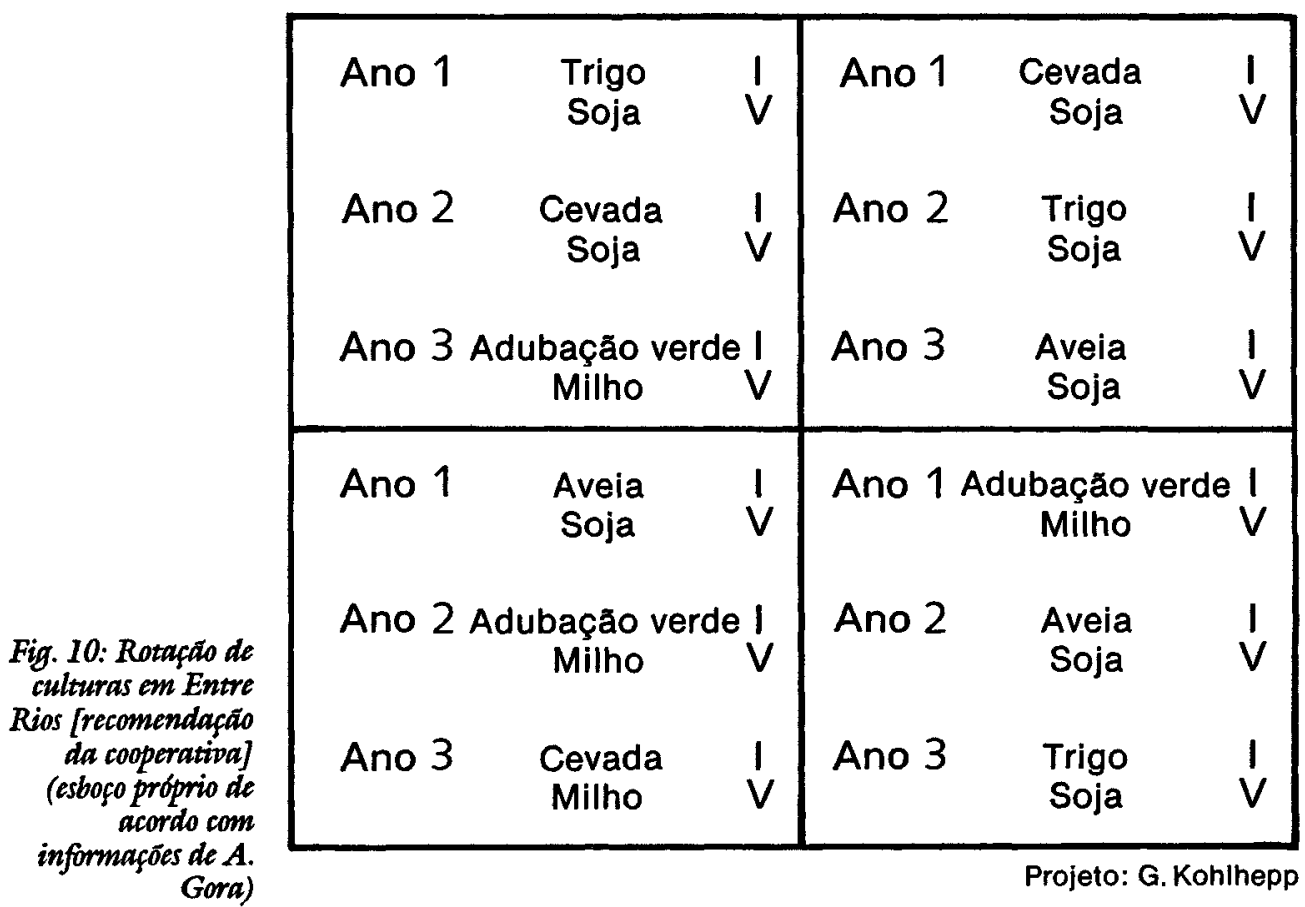


Uma vez que, devido a imposiçóes do sistema de rotação, a área de cultivo da cevada nos arredores de Entre Rios não pode ser aumentada ao bel-prazer, a cooperativa agrária procurou, desde fins da década de 70, apoiar e propagar, por meio de assistentes próprios, o cultivo da cevada nas regióes com condiçóes favoráveis para tanto no sul do Brasil (vide fig. 11). Assim ficou garantido o abastecimento da unidade de maltagem através da compra de produtos "nacionais", mesmo quando a produtividade e, com isto, o volume da safra em Entre Rios esteve seriamente afetada pela incidência de fungos e por esterilidade das espigas (vide figs. $12 \mathrm{e} \mathrm{13).} \mathrm{Hoje} \mathrm{estas} \mathrm{doenças,} \mathrm{sérias} \mathrm{ameaças,} \mathrm{puderam} \mathrm{ser}$ - em colaboraçáo com a Universidade Técnica de Munique (Weihenstephan) - combatidas com sucesso e a produtividade no cultivo da

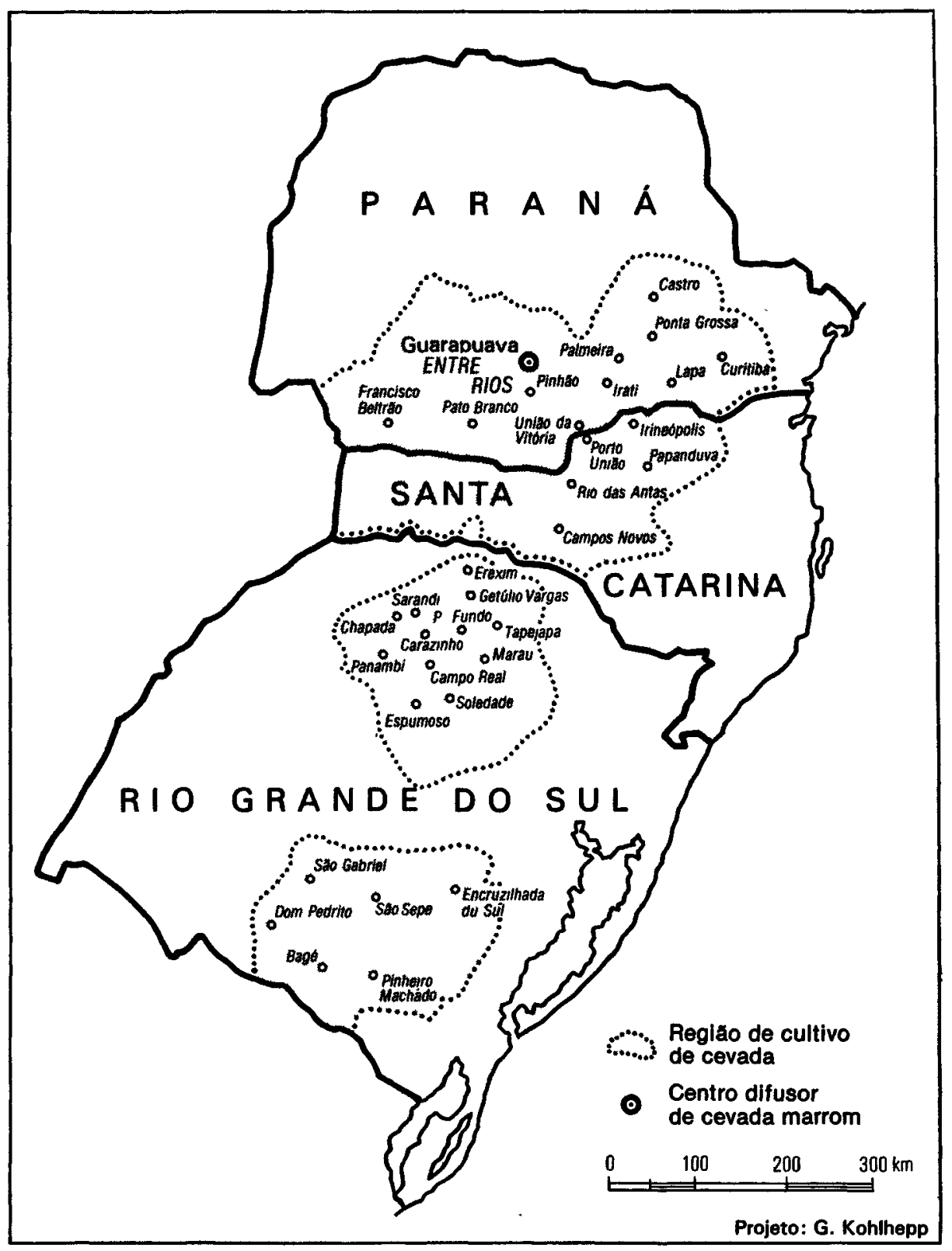

Fig. 11: Difiusão de cultipo de cevada $n$ sul do Brasil (conforme documentos da empresa Agromalte $S$. A. em Vitoria/Entre Rios) 


\section{Entre Rios/PARANÁ \\ produtividade}

Fig. 12: Evolucã̃o da produtividade da cepada marron em Entre Rios (fonte: vide fig. 3)

Fig. 13: Evolufão da area plantada $e$ da produção de cepada marrom [Coop. Agrairia Entre Riose aquisif̧̃̃o por Agromalte] (fonte: vide fig. 11)

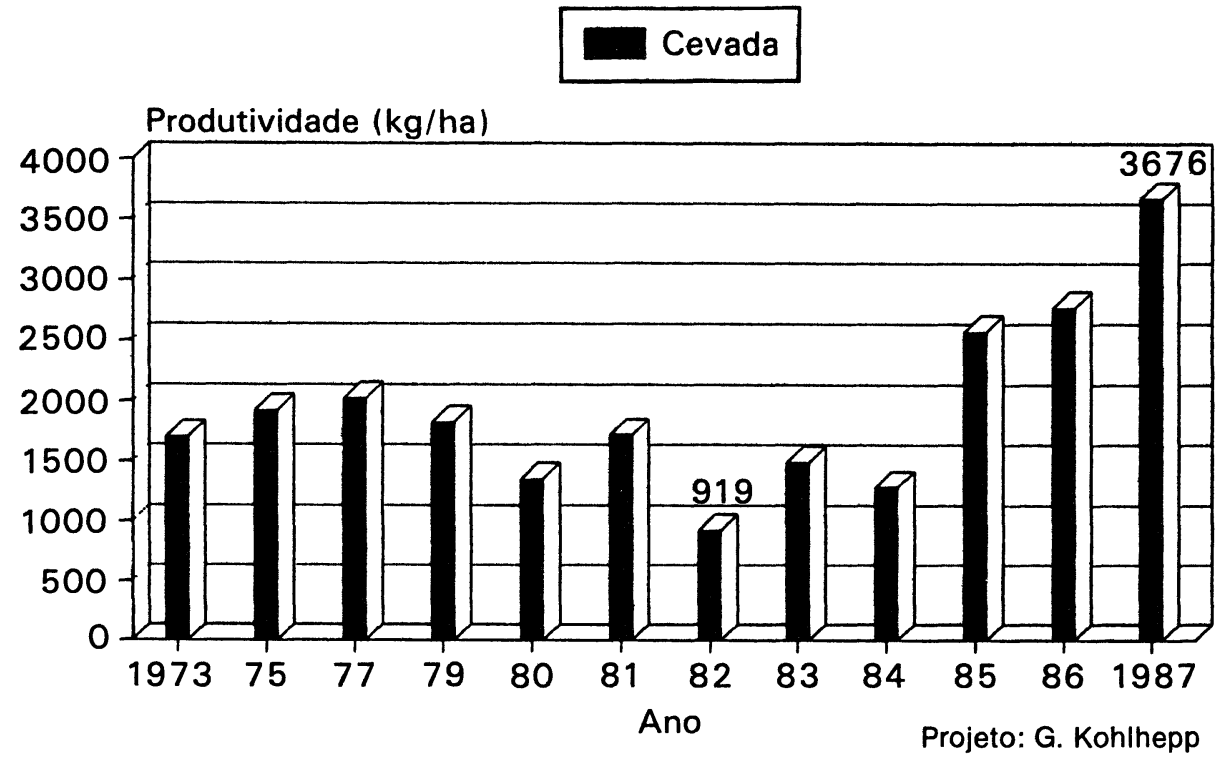

cevada alcançou valores recorde nos últimos anos (vide fig. 12). Depois da fase de maior redução da área de cultivo em 1983 (2.300 ha), hoje a cevada ocupa, com 17.000 ha, o segundo lugar entre os produtos agrícolas depois da soja.

É praticamente impossível exagerar a importância para as empresas, mas também para o mercado de trabalho, de um cultivo de cevada tecnicamente fundamentado, com fonte de renda garantida, propiciando, através da introdução de uma cultura de inverno, empregos para o ano todo.

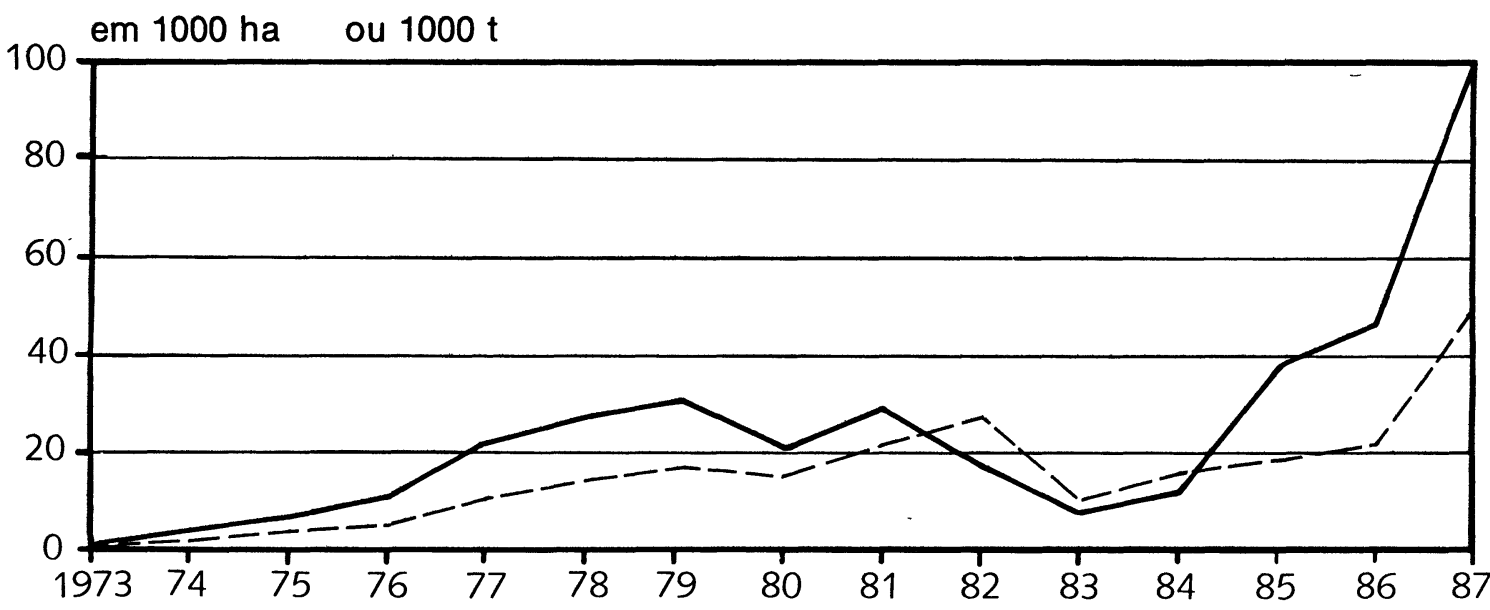

— Produção ( $\mathrm{t}$ )

Projeto: G. Kohlhepp

- - Área cultivada (ha) 
A difusão desta inovação, que partiu de Entre Rios e, em poucos anos, se espalhou no Paraná e nos Estados adjacentes ao sul, ainda é reforçada pelo fato de que a Agromalte controlava, em 1987, com a produção própria da Cooperativa Agrária em Entre Rios e os contratos de fornecimento, $46,5 \%$ da área de cultivo e $52,1 \%$ da safra de cevada no Brasil. Sobretudo a partir de 1984 foi possível constatar enormes aumentos, devido ao aumento de produtividade, e, a partir de 1986, pela ampliaçáo das áreas de cultivo (vide fig. 13). Só os colonos suábios do Danúbio na regiáo dos campos de Guarapuava detinham, em 1987, 22,8\% das áreas de cultivo das empresas fornecedoras da Agromalte e produziam $40,1 \%$ da cevada utilizada pela unidade de maltagem em vitória. A parcela dos cooperativistas na área total de cultivo e na produção de cevada no Brasil montava, neste mesmo ano, a 10,6 e $20,9 \%$ respectivamente. A produtividade destas empresas esteve, em 1987, em volta dos $3.676 \mathrm{~kg} / \mathrm{ha}$ e é comparável à das empresas da Europa central e ocidental.

A unidade de maltagem em vitória fornece hoje em dia $40 \%$ da produção brasileira de malte, o que, considerando-se uma demanda de malte de cerca de $560.000 \mathrm{t}$ em 1988, cobre e também cobrirá, no futuro, apenas um terço da demanda nacional (6).

Os dois conglomerados de cerveja no Brasil, a Brahma e a Antárctica, também possuem unidades de maltagem próprias. Mas enquanto a Antárctica, que se abastece em $80 \%$ na Agromaltine, está altamente interessada em aumentar a produçăo nacional de cevada e malte, a Brahma confia mais - dependendo dos preços de malte no mercado mundial - nas importaçóes, sobretudo de uma unidade de maltagem própria na Argentina. Uma vez que os proprietários da Agromalte estão interessados numa dispersão das vendas e fornecem cerca de $20 \%$ da produção para fregueses menores, nos últimos anos algumas cervejarias menores, que antes haviam sido expulsas do mercado pelo monopólio dos conglomerados e pela dificuldade de importar o malte, retomaram as suas atividades no Brasil.

Com a aquisiçáo da unidade de maltagem pela cooperativa suábiodanubiana foram colocaods à disposição - além da criação de $200 \mathrm{em}$ pregos diretos - recursos adicionais para reservas, projetos de compra de terras, assim como para instituiçóes sociais em Entre Rios.

\section{A Cooperativa Agrária como Agente Multifuncional}

A cooperativa agrária tem sido, tanto no passado quanto no presente, de enorme importância e, vista como um todo, mesmo essencial para a colônia de Entre Rios. Mesmo que o papel principal da coopera- 
tiva, que também tem alguns luso e não-brasileiros entre os seus associados, seja o reforço econômico da colônia, suas atividades públicas, sociais e culturais em prol de Entre Rios já văo muito além deste setor.

O foco central destas atividades é composto de assistência aos colonos, comercialização da produção agropecuária, disposição de meios de produçáo e organizaçáo de créditos no mercado financeiro. Desde cedo os superávits foram aplicado como reinvestimento na ampliação da cooperativa, que, por sua vez, investia seus fundos de capitais em projetos de terra para pequenos ou jovens colonos e socorria estabelecimentos ameaçados por más safras, procurando saneá-los à base de uma rígida disciplina. Através de métodos modernos de processamento e de beneficiamento (unidade de maltagem, moinhos de trigo e de arroz, fábrica de forragens, moinhos de calcário, serraria) e da ampliaçáo das capacidades de secagem, limpeza e sobretudo armazenagem (cerca de $200.000 \mathrm{t}$ ), foram criadas as condiçōes para o sucesso econômico. Com um volume médio de negócios de 80 a 100 milhóes de dólares nos últimos anos a Agrária faz parte das dez maiores cooperativas do Brasil. Desde que Entre Rios foi ligado à rede telefônica em 1970, há contato direto com os mercados nacionais e internacionais, inclusive com a bolsa da soja de Chicago (GAPPMAIER 1987).

O supermercado, com uma oferta bem selecionada, as oficinas e o comércio de máquinas e peças sobressalentes são considerados sobretudo como serviços eferecidos aos associados da cooperativa. Uma companhia própria de transportes está encarregada de abastecer as empresas agrícolas com combustíveis e de realizar parte dos transportes de frete.

Um departamento técnico muito bem equipado com engenheiros agrônomos e agrotécnicos, bem como máquinas, dirige sobretudo as extensas atividades experimentais e assistenciais no setor agropecuário. Para estes fins estão à disposição uma empresa experimental com 120 ha de extensão e um moderno equipamento de máquinas. As atividades concentram-se em experiências para a obtençăo de novas espécies, métodos de melhoramento das sementes, novas rotaçóes (entre outras também o cultivo de leguminosas para a adubação verde (vide fig. 10) e métodos de cultivo específicos para o local a fim de preservar a fertilidade do solo e evitar a erosáo (JASTER 1983, 1986).

As principais marcas do sucesso da cooperativa, além da boa organizaçáo interna e da absoluta confiança entre a administraçáo e os associados, são a decidida defesa dos interesses da cooperativa para fora.

Graças às atividades da competente direçáo foi possível quebrar a posiçáo isolacionista inicial, que se originara por questôes lingüísticas e de mentalidade, e estabelecer ótimos contatos com bancos, empresas comerciais, fornecedores e fregueses, com entidades governamentais em Curitiba e também em Brasília. 
A incorporaçáo de Entre Rios em uma rede internacional de fornecimento de recursos auxiliares no âmbito da assistência ao desenvolvimento por parte do Primeiro Mundo deve ter sido uma das medidas decisivas da diretoria da cooperativa, que, desde 1966, estabelece as metas para o desenvolvimento da associaçáo. Não somente a República Federal da Alemanha, através do Ministério da Cooperaçăo Técnica (BMZ), as unidades federais Baviera e Baden-Württemberg, como estados patrocinadores dos suábios do Danúbio, mas também a Áustria e o Estado de Tirol forneceram auxílios de pessoal e de equipamento. A cidade de Rastat patrocina Entre Rios.

Entre Rios tornou-se conhecida pelo trabalho realizado pelos suábios do Danúbio, mas também pelas inteligentes atividades no campo das relaçóes públicas: na Alemanha e na Áustria, como um dos poucos exemplos de uma emigraçáo coesa de refugiados descendentes de alemães; no Brasil, por ser um modelo exemplar de uma colonização agrícola que ressalta as próprias possibilidades de desenvolvimento, capaz de servir de enfeite a todo e qualquer governo. Altos e altíssimos representantes de estado visitaram Entre Rios: Governadores e ministros alemães, governadores, ministros e secretários estaduais brasileiros e finalmente, em 1973, até mesmo o presidente da República Ernesto Geisel.

A cooperativa de Entre Rios assumiu diversas funçōes públicas e, com isto, aliviou a administraçáo municipal de Guarapuava e outras entidades governamentais: a construção de rodovias e a sua manutenção com máquinas próprias na área da colônia, abastecimento com energia elétrica (até 1971) e água através da construção de uma canalizaçáo de água, instalação de depósitos de água e poços, construçáo de um hospital, manutenção de um posto policial.

Destacam-se igualmente as atividades da cooperativa no setor escolar, que é composto de um jardim de infância, do pré-primário e do curso primário e secundário. Este último dispóe de uma profissionalização em agropecuária. A língua de ensino é o português, mas o ensino em língua alemá, apoiado pelo envio de professores e material escolar da Alemanha e da Austria, está integrado no currículo brasileiro. Também a escola municipal é em parte sustentada pela cooperativa, que também apoia o trabalho das irmãs católicas no setor social. No setor social e cultural precisa ainda ser mecionado o centro juvenil e estudantil (com bilioteca), que está encarregado de incentivar uma vida ativa na comunidade e oferece um vasto programa cultural. Há pouco tempo atrás foi inaugurada uma estação de rádio. Coros, grupos de teatro, diversos conjuntos musicais e grupos de dança folclórica ocupam uma função importante $\mathrm{e}$ já possibilitaram aos seus membros diversas viagens pelo Brasil e ao estrangeiro, inclusive à Alemanha e à Áustria. 
A cooperativa apóia igualmente os clubes recreativos dos povoados, a "Casa dos Suábios do Danúbio" em. Vitória, um amplo departamento esportivo e o centro de lazer.

No espectro destas funçóes a cooperativa é náo só um fator de relevo para a organização espacial no âmbito da modernizaçáo da agropecuária (KARP 1986), mas também um promotor de interesses socioculturais, que servem à estabilizaçáo do grupo étnico-social.

Além disto, a Cooperativa Agrária uniu-se às cooperativas dos holandeses e dos menonitas nos Campos Gerais orientais sob a sigla de Cooperativa Central Coopersul, a fim de abastecer-se em conjunto com meios de produçáo, promover a comercializaçáo dos produtos agrícolas e incentivar a ampliação da agroindústria e da cooperaçáo agrotécnica. E com $43 \%$ a sua participação neste órgáo de integração econômica possui um peso considerável.

\section{Persistência como Grupo Étnico-Social: Aspectos do Desenvolvimento Populacional}

Nos anos 1951/52, 2.446 pessoas emigraram para entre Rios, das quais $28,1 \%$ tinham menos de 16 anos enquanto que $65,1 \%$ pertenciam à faixa entre os 16 e os 60 anos. Até 1971 um total de 1.776 pessoas deixou Entre Rios, de modo que, considerando-se os movimentos naturais de populaçáo neste período, a 31 de julho de 1971 ainda havia 1.512 suábios do Danúbio em Entre Rios (HOCHGATTERER 1986, p.108). De acordo com um levantamento realizado em maio de 1988 (7), moram 1.539 pessoas de origem suábio-danubiana nos cinco povoados da colônia. Isto significa que o êxodo nos últimos anos foi bem menor que na fase inicial, mas que umas 500 a 550 pessoas devem ter emigrado, o que justificaria o número quase igual de habitantes em 1971 e 1986. Na estrutura etária, o grupo dos menores de 16 anos consta com $28,4 \%$, a faixa dos 16 aos 60 anos com $61,6 \%$. A populaçáo com mais de 60 anos responde por 14,3\% (1952: 6,8\%), o que revela uma visível mudança da estrutura etária. Na pirâmide etária da população suábio-danubiana de 1980 (vide fig. 14) pode-se observar que, depois de uma queda considerável do número de filhos na década de 70 , hoje manifestada na pequena representaçáo das faixas de 10 a 14 e de 15 a 19 anos, há agora um aumento significativo no grupo das crianças com menos de 10 anos. Isto leva a crer, contanto que náo haja êxodo, numa consolidaçáo, mesmo que o número de filhos permaneça reduzido (8).

Esta consolidação de fato faz-se mister, pois o número de habitantes dos povoados de Socorro (139 pessoas, 42 domicílios, dos quais 10 são pensionistas) e Cachoeira (209 pessoas, 61 domicílios) encontra-se no limite inferior de uma capacidade de existência como povoado autô- 


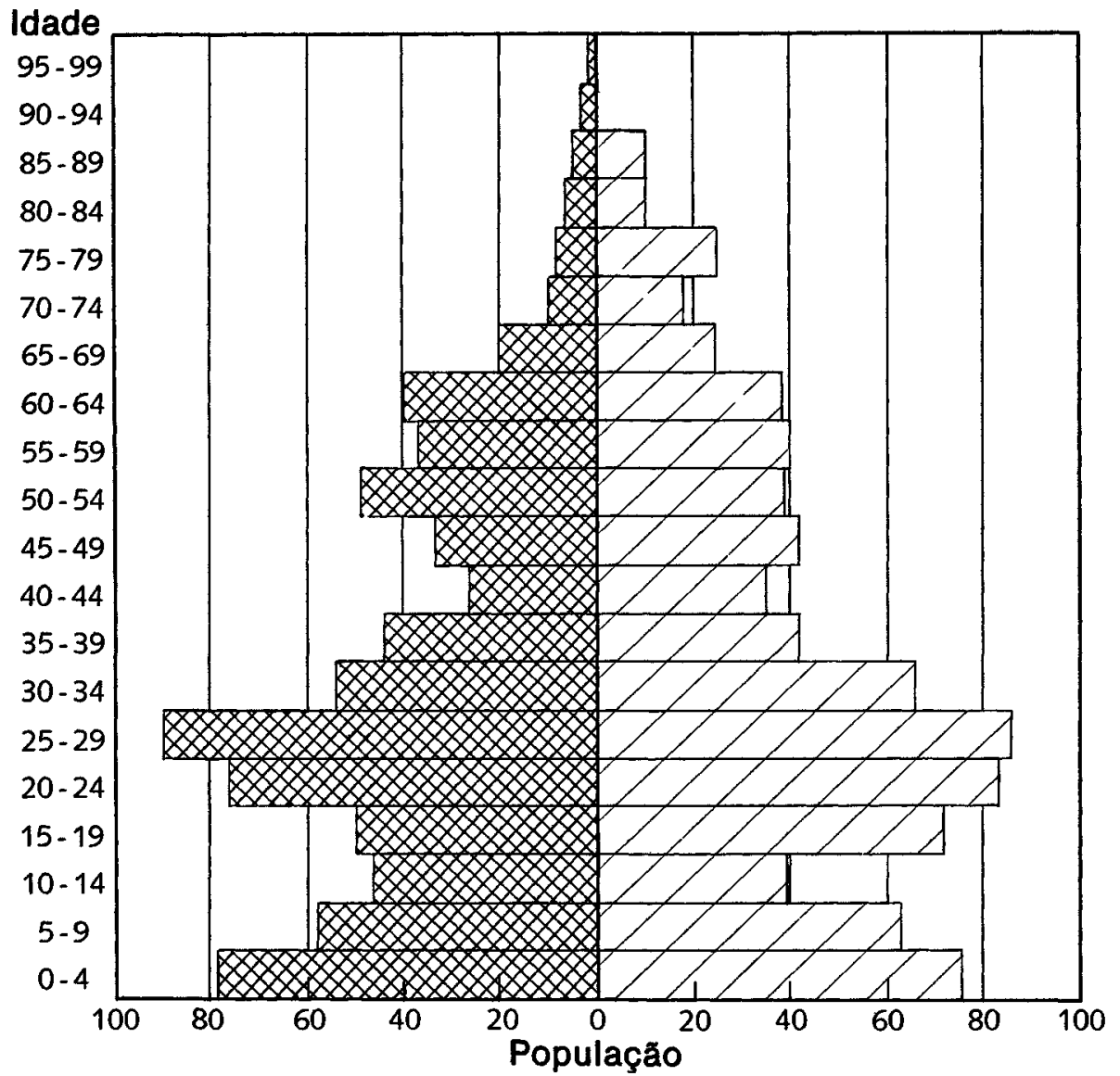

Homens

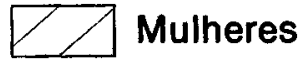

Projeto: G. Kohlhepp
Fig 14: Estrutura etaria da populagáo " suábia-danúbio" em Entre Rios 1988 (esboso próprio baseado em levantamento de Johanna $E$. Michelz, maio 1988, Universidade de Guarapuava)

nomo, sobretudo considerando-se o equipamento funcional ínfimo. $\dot{E}$ importante que o poder de atraçáo de Vitória, que abriga $41 \%$ da populaçáo suábio-danubiana, sobre os povoados vizinhos sofra uma redução. Podem ser considerados fatores positivos para este efeito as curtas distâncias entre os povoados, as rodovias, hoje asfaltadas, e o grande número de automóveis, que permitem um movimento de ida e volta.

A estabilização do número da população de suábios do Danúbio é também importante para possibilitar a ocupação do leque diversificado de funçóes, até um certo âmbito, por membros do próprio grupo étnico-social. $\mathrm{E}$ mesmo a possibilidade de matrimônios dentro do próprio grupo depende de um tamanho mínimo deste mesmo grupo.

Ao todo, a composição étnica da população no distrito de Entre Rios, município de Guarapuava, alterou-se muito. A crescente importância da cooperativa como fornecedora de empregos, em 1980 quase 1.000 , a contratação de trabalhadores rurais, assim como o de empregadas domésticas, levaram a um forte afluxo de populaçáo luso-brasileira 
a Entre Rios. Hoje a população de não-suábios do Danúbio deve estar acima de 10.000 habitantes.

Uma vez que náo existem planos-diretores fixos para os povoados, também ocorreu o assentamento de máo-de-obra luso-brasileira em casebres de madeira na periferia dos povoados, no local em que antes ficavam as malhadas. Para evitar o perigo da formação de favelas a cooperativa ergueu, nos limites meridionais de Vitória, em frente ao bairro industrial, uma vila operária equipada com escola, igreja e centro social. Como o afluxo de populaçáo deve continuar, mesmo sem a criação de novos empregos, é de se esperar que ocorra um adensamento da área construída e um aumento do potencial de conflitos, que - devido às enormes disparidades sociais - poderá se transformar em um dos mais difíceis problemas a serem solucionados no futuro.

\section{Integração ou Segregação?}

Nos campos de Guarapuava ocorreu, desde os anos 50, uma marcante mudança das estruturas do espaço social e econômico. Os suábios do Danúbio transformaram, através da atuaçăo inovadora e do sucesso econômico decorrente, um espaço passivo em uma das regióes rurais economicamente líderes no Paraná e até mesmo no sul do Brasil. Eles não só revezaram os fazendeiros de gado na sua posiçáo de liderança regional, como também passaram por um processo de transformação social interna: de imigrantes e pequenos agricultores pouco capitalizados a fazendeiros bem situados dispondo de uma estrutura empresarial consolidada. E tudo isto como grupo etnicamente ainda homogêneo. Este processo foi certamente marcado tanto pelo "espírito econômico" atribuído aos suábios do Danúbio - ou seja: tradiçáo na agropecuária, capacidade de persistência, disponibilidade para a inovaçáo, consciência cooperativista e, em sentido especial, luta pela subsistência de um grupo de refugiados - quanto pela pressão de adaptação econômica.

A posiçáo destacada como pioneiros de uma agricultura integralmente mecanizada e os efeitos de difusáo daí partidos para os campos limpos paranaenses cederam a uma integração no processo de modernizaçáo da agropecuária brasileira.

Graças à sólida base financeira da cooeprativa, os suábios do Danúbio souberam enfrentar a restriçáo espacial sofrida pelo aumento proibitivo dos preços da terra e, com isto, interromper o círculo vicioso de um êxodo da geraçáo seguinte. A dinâmica espacial concentrou-se no espaço vital imediato, no qual se preservou a relaçáo com a agropecuária, apesar da mobilidade social. Não se conhece o absenteísmo. A função diretriz da cooperativa foi facilitada pela coesão do grupo étnico. 
O sucesso econômico em uma situação de concorrência e a homogeneidade étnica são, sem dúvida, dados a gerar acusaçôes de segregaçáo e a promover a inveja social, ainda mais quando o desenvolvimento foi facilitado por impulsos externos. Mas o que ocorreu náo foi somente uma integração econômica perfeita e efeitos de irradiaçáo positivos para o centro urbano de Guarapuava e em âmbito supra-regional. Houve também sucessos decisivos no campo da integraçáo sócio-cultural. A consciência da tradiçáo e a preservaçáo da herança cultural não devem ser confundidos com falta de vontade para a integraçáo social. A segregaçáo espacial está sendo reciuzida cada vez mais pelo afluxo de população luso-brasileira, o que, por outro lado, deixa as diferenças sociais bem nítidas. A disposição para a integração de grupos de imigrantes e seus descendentes é, na sociedade brasileira, medida bem mais pelo comportamento deste grupo frente a outros grupos étnicos do que frente a extratos sociais subprivilegiados. Os suábios do Danúbio precisam tentar satisfazer a ambos os níveis, na sua tentativa de dar forma ao seu espaço social e eliminar as disparidades sociais.

Os colonos de Entre Rios, o único assentamento suábio-danubiano coeso no ultramar, conseguiram manter durante quase quarenta anos a sua identidade como grupo étnico-social com traços sócio-econômicos e culturais distintos. Mas lhes foi possível, no entanto, estabelecerem-se como conscientes cidadãos brasileiros.

\section{Notas}

1 Os motivos responsáveis pela persistência do paradigma " floresta = área favorável para a agricultura" sāo vários e podem ser achados, entre outros, na baixa intensidade de capital da "colonizaçăo de florestas" realizada no sistema tradicional de agricultura de rotaçáo com queimadas; por outro lado na intensiva adubaçăo e emprego de equipamentos, nos conhecimentos agropecuários, assim como nas condiçóes de posse na regiāo dos campos.

2 Parte da comunidade menonita emigrou para o Rio Grande do sul e fundou, na campanha perto de Bagé, a Colónia Nova, que, após ter problemas no cultivo de trigo, reorientou-se igualmente para a criaçăo de gado leiteiro. Nos arredores já fora feita, em 1925, uma tentativa de colonizaçăo dos campos por imigrantes alemães (Hulha Negra) (KOHLHEPP 1969).

3 Vide LENDL 1941, SCHRAMM 1972, HOCHGATTERER 1986 e GAPPMAIER 1987.

4 Cf. processos semelhantes em outra colônias nos campos limpos do Paraná e no Rio Grande do Sul (KOHLHEPP 1969) assim como processos de compra de terras por estrangeiros abastecidos junto aos menonitas no charco paraguaio (KOHLHEPP 1948b).

5 Gentil informação do Sr. Mathias Leh, 23.1.1989. 
6 Todas as informaçóes de acordo com material estaútico da Agromalte S. A., da Cooperativa Agrária Mista Entre Rios Ltda., assim como por gentis informaçöes do Sr. Francisco R. Essert, diretor de vendas da Agromalte S. A., em agosto de 1986.

7 Estes dados, colhidos pela Sra. Johanna E. Micheltz (Universidade da Guarapuava), foram gentilmente cedidos ao autor em agosto de 1988 . Um levantemento do número de pessoas, efetuado por J. Lichtenberger c A. Gappmaier para 1980, deu um resultado de 1.503 habitantes (segundo: HOCHGATTERER 1986, p. 106).

8 De acordo com os dados de maio de 1988 obrém-se um valor estatístico de 2,6 filhos por familia, sendo que os valores para as familias agricolas e năo-agricolas praticamente não diferem.

As pesquisas foram realizadas graças ao gentil apoio da DFG (Sociedade Alemã de Pesquisas) que, já no âmbito de trabalhos de geografia social e económica anteriores no sul do Brasil e no Paraná nos anos de 1965 e 1970, possibilitou o surgimento de estudos sobre a colonizaçăo agrária suábio-danubiana no Paraná.

O autor agradece ao Sr, Mathias Leh, presidente da Cooperativa Agrária Mista Entre Rios Ltda, e ao Sr. eng. agrônomo Anton Gora, gerente técnico, pelo apoio na realizaçáo deste estudo de caso.

\section{Resumo}

Suábios do Danúbio no Brasil. Processos de desenvolvimento dos espaços social e económico da colónia de refugiados Entre Rios no Paraná.

Desde a sua imigração no Paraná em 1951/52 os agricultores suábios do Suábio fazem parte dos inovadores agropecuários mais consideráveis nos campos limpos do sul do Brasil. apesar de um constante processo de concentração fundiária e, em conseqüuéncia disto, de uma crescente diferenciaçăo social, foram as atividades eficazes da cooperativa agrícola de aquisição de novas terras, de uma reforma agrária interna, de consolidação da estrutura dos estabelecimentos agrícolas e de estabilização da colônia central, que garantiram a preservação dos suábios do Danúbio como grupo érnico-social. Depois de passar pelos "booms" do arroz, do trigo e da soja hoje se procura alcançar uma rotaçăo de culturas equilibrada, com alternativas especfficas para a regiăo nas semeadas de inverno, onde especialmente a cevada (destinada à fabricação de cerveja) desenvolve uma funçäo inovadora e difusora. marcada pelas atividades dos suábios do Danúbio, a transformação estrutural dos espaços agrário e social nos Campos de Guarapuava, com seus efeitos de irradiaçăo regional e de integraçăo no processo de modernizaçáo da agricultura brasileira, $t$ acompanhada de sforços de integraçăo sociocultural. Mesmo com isto Entre Rios, a únion colónia coesa de suábios do Danúbio do ultramar, preservou a sua identidade étnico-social.

\section{Abstract \\ Spatially effective agrarian activities of ethno-social groups in Brazil. The example of Danube Swabian settlers in Entre Rios/Parand.}

Since their immigration to Parand in 1952 Danube swabian furmers bave belonged to the most important innovators in agriculture on South-Brazilian Campos Limpos. The efficient activities of the agrarian cooperatipe have safeguarded the axistence of the Danube Swabians as an ethmo-social 
group by means of land purchase, internal land reform, consolidation of farm structure and stabilization of the core settlement despite continuing land concentration and social differentiation. Following the rice, wheat and soja booms, a balanced crop-rotation with sustainable winter crop alternatives is today the central aim. Barley for brewing has gained a special function in the innovation and diffusion of innovations. Danube Swabian caused agro and socio-spatial structural changes on the modernization process of Brazilian agriculture is accompanied by attempts at socio-cultural integration. Nepertheless, Entre rios, the only concentrated settlement of Danube Swabians in overseas, has retained its ethno-social identity.

\section{Bibliografia}

Agrdria = Cooperativa Agrdria Mista Entre Rios Ltda. (1985): Bericht des Verwaltungsrates über das Geschäftsjahr 1984/85. -- Entre Rios.

Agrária(1987a): Bericht des Verwaltungsrates über das Geschäftsjahr 1986. - Entre Rios.

Agraria (1987b): Relatório/Jahresbericht 1986. - Curitiba.

Agrária (1988): Berichr des Verwaltungsrates über das Geschäftsjahr 1987. - Entre Rios.

BALHANA, A. PILATTI (1963): Mudança na estrutura agrária dos Campos Gerais. Boletim da Universidade do Paraná, Dep. de História (Curitiba), 3, pp. 28-52.

BREPOHL, F. W.; FUGMANN, W. (1927); Die Wolgadeutschen im brasilianischen Bundesstaat Paraná. - Sturtgart.

ELFES, A. (ed.) (1971): Donauschwaben in Paraná. - Curitiba.

FOUQUET, C. (1974): Der deutsche Einwanderer und seine Nachkommen in Brasilien 1808-1824-1974. - São Paulo, Porto Alegre.

FRÖSCH, M. (1958): Guarapuava, die donauschwäbische Flüchtlingssiedlung in Brasilien. - Freilassing (Donauschwäbische Beiträge, 28).

GAPPAMAIER, J. (1986): Entre Kius. Die Siedlung der Donauschwaben in Paraná Brasilien 1951-1986. - Vitória.

GAPPMAIER, J. (1987): Entre Rios. Agrargeographie der Donauschwabensiedlung in Paraná, Brasilien. - Diss., Salzburg.

GRUBER DE ABREU, A. Th. (1981): A posse e o uso da tera. Modernizaçăo agropecuária de Guarapuava. - Curitiba.

HOCHGATTERER, A. (1986): Entre Rios. Donauschwäbische Siedlung in Südbrasilien. - Salzburg.

JASTER, F. (1983): Die Landwirtschaft von Entre Rios 1982. - Entre Rios (inédiro).

JASTER, F. (1986): Zur Lage der Landwirtschaft in Entre Rios. - Entre Rios (inédito).

KARP, B. (1986): Das agrare Genossenschaftswesen als raumgestaltender Faktor. Zur Ambivalenz gelenkter Modernisierung am Beispiel von West-Paraná (Bralsilien). - Geographische Zeitschrift, 74, pp. 241-250. 
KARP, B. (1987): Agrarkolonisation, Landkonflikte und dipatitäre Regionalentwicklung im Spannungsfeld ethno-sozialer Gruppen und externer Einflubfaktoren in West-Paraná (Brasilien). - In: KOHLHEPP, G. (ed.): Brasilien. Beiträge zur regionalen Strukturund Entwicklungsforschung. Tübingen, pp. 39-69 (Tübinger Beiträge zur Geographischen Lateinamerika-Forschung, 1).

HOHLHEPP, G. (1969): Types of agricultural colonisation on subtropical Brazilian Campos Limpos. - Revista Geográfica (Rio de Janeiro), 70, pp. 131-155.

KOHLHEPP, G. (1975): Agrarkolonisation in Nord-Paraná. Wirtschafts- und sozialgeographische Entwicklungsprozesse einer randtropischen Pionierzone Brasiliens unter dem Einflub des Kaffeeanbaus. - Wiesbaden (Heidelberger Geogr. Arb., 41).

KOHLHEPP, G. (1975/76): Die Bedeutung der deutsch-brasilianischen Bevölkerung zur Siedlungs- und Wirtschaftsentwicklung Südbrasilines. - Staden-Jahrbuch (São Paulo), 23/24, pp. 77-94.

KOHLHEPP, G. (1984a): Die brasilianische Auswanderung nach Ost-Paraguay. Zur Analyse von Ursachen, Ablauf un Konsequenzen. - Staden-Jahrbuch, 32, pp. 21-56.

KOHLHEPP, G. (1984b): Strukturwandel und Beharrungsvermögen der Mennoniten im paraguayschen Chaco. Zur wirtschaftlichen Entwicklung religiöser Gruppensiedlungen an der agronomischen Trockengrenze. - In: Paraguay. Lateinamerika-Srudien, 14, pp. 255-286.

KOHLHEPP, G. (1989): Strukturwandlungen in der Landwirtschaft und Mobiliät der ländlichen Bevölkerung in Nord-Paraná (Südbrasilien). - Geographische Zeitschrift, 77, pp. 42-62.

LEH, M. (1983): Die Siedlung Entre Rios im Krisenjahr 1983. - Entre Rios (inédito).

LENDL, E. (1941): Die donauschwäbische Kulturlandschaft. - Mittelungen der Geographischen Gesellschaft Wien, 84, pp. 202-222.

LÜCKER, R. (1986): Agrarräumliche Entwiccklungsprozesse im Alto-Uruguai-Gebiet (Südbrasilien). Analyse eines randtropschen Neusiedlungsgebietes inter Berücksichtigung von Diffusionsprozessen im Rahmen modernisierender Entwicklung. - Tübingen (Tübinger Beiträge zur Geographischen Lateinamerika-Forschung, 2).

MAACK, R: (1968): Geografia física do Estado do Paraná - Curitiba.

PAULS, P. J. (1980): Mennoniten in Brasilien. Gedenkschrift zum 50 Jahr-Jubiläum ihrer Einwanderung 1930-1980. - Witmarsum.

PFEIFER, G. (1967): Kontraste in Rio Grande do Sul: Campanha und Alto Uruguai. Geographische Zeitschrift, 52, pp. 163-206.

PFEIFER, G. (1973): Deustche Bäuerliche Kolonisation in den Vereinigten Staaten und Brasilien. Konvergenzen und Kontraste. - Köln (Kölner Goegr. Arbeiten, 30), pp. 37-54.

PFEIFER. G.; KOHLHEPP, G. (1969): Wirtschafts- und sozialgeographische Studien in Südbrasilien. - Forschungsbericht, pp. 1-129. Heidelberg (inédito).

SCHRAMM, J. (ed.) (1972): Beiträge zur Kenntnis der Donauschwaben. Gedenkschrift für Frierich Metz. - Sturtgart. 
VAN SANTEN, C. M. P. (1966): Die holländischen Bauernsiedlungen in Brasilien. Staden-Jahrbuch, 4, pp. 103-120.

WAIBEL, L. (1955): Die europäische Kolonisation Südbrasiliens. - Bonn (Org. e prefácio G. PFEIFER) (Colloquium Geographicum, 4).

WIELNAD, L. (1969): Das Weizenwunder von Paraná. - Zeitschrift für Kulturaustausch (Stuttgart), 19, 3, pp. 312-315.

WILHELMY, H. (1940): Wald und Grasland als Siedlungsraum in Südamerika. - Geographische Zeitschrift, 46, pp. 208-219. 